\title{
SPOŁECZNOŚĆ I HISTORIA, CZYLI PIENIĄDZ I KREW EKONOMIA W VADE-MECUM NORWIDA
}

\author{
Są to rzeczy gorzkie, może głębokie, może dziwne - - niezawodnie potrzebne! \\ C. Norwid, List do H. Merzbacha, PW IX, 228. \\ Mówią, że Postęp nas bogaci co wiek; \\ - Bardzo mi to jest miło i przyjemnie - \\ Niestety! co dnia mniej cieszę się ze mnie, \\ Śmiertelny człowiek! \\ (Sieroctwo PW II, 42-43)
}

Literatura pozwala odkryć w pieniądzu więcej niż jeden sens ${ }^{1}$.

Już oświeceniowi krytycy określili romantyka mianem homo metaphisicus, tak też zwykliśmy postrzegać romantyzm i dziś: jako epokę upatrującą celu ludzkich wysiłków oraz przedsięwzięć (także intelektualnych) w pozadoczesnym, niematerialnym wymiarze istnienia. Problem w tym, że w wieku XIX do rangi nowej metafizyki awansowała (a przynajmniej awansować usiłowała) ekonomia, co z idealistycznego (i nie tylko) punktu widzenia urągało „filozofii pierwszej”. Uwarunkowania gospodarczo-społeczne stulecia sprawiły jednak, że wbrew antymaterialistycznym deklaracjom pieniądz silnie przyciągnął uwagę romantyków, a krytyka kapitalizmu przybrała wręcz charakter „pozy romantycznej”" . Filozofowie

\footnotetext{
1 J. HöRISCH, Orzeł czy reszka. Poezja pieniądza, przeł. J. Kita-Huber, S. Huber, Kraków 2010, s. 52.

2 Zob. M. A. CісноскI, Wieczna gra możliwości - rzecz o politycznym romantyzmie niemieckim, „Nowa Res Publica” 1998, nr 7-8 (118-119), lipiec-sierpień, s. 42-44.
} 

i politolodzy niejednokrotnie dzielili się z literaturoznawcami swym zaskakują-
cym spostrzeżeniem, że

Autor publikacji pisze o romantykach niemieckich, że byli oni „nieprzejednanymi przeciwnikami wolnego handlu, kapitalistycznej gospodarki oraz ekonomicznej supremacji mieszczaństwa": „W ich koncepcjach państwa wciąż powracają teorie społeczeństwa stanowego, wspólnoty majątkowej oraz kontroli władzy nad aktywnością gospodarczą ludzi” (tamże, s. 43). Chociaż krytyka kapitalizmu i industrializacji osiągnęła różny stopień u różnych niemieckich myślicieli, a podawane przez nich recepty były dość różne, to jednak traumatyzacja obrazu ówczesnej rzeczywistości gospodarczej stała się cechą wspólną ich wypowiedzi i twórczości. Podobną prawidłowość można zaobserwować na gruncie polskim. Zob. Z. STEFANOwSKA, Romantyczny stosunek do finansów publicznych oraz E. Nawrocka, Buchalteria i duchowość (Stowacki i pieniądze), w: Pieniądz w literaturze i teatrze, Materiały z sympozjum , Temat pieniadza w literaturze $i$ teatrze”. Uniwersytet Gdański, Gdańsk 17-18 stycznia 2000, pod red. J. Bachórza, Sopot 2000, s. 68-73 oraz 74-88; K. Czeczot, Romantyczny antykapitalizm, oprac. M. Pospiszyl, Warszawa 2018.

Na literackim gruncie polskim już u zarania XIX wieku pieniądz stał się obiektem zainteresowania pasjonującego się mineralogią i geognozją Maurycego Mochnackiego, który postrzegał złoto jako rodzaj podziemnego, fascynującego i zarazem diabolicznie niebezpiecznego, primum mobile:

„Po wieleż to razy złorzeczyliśmy i błogosławiliśmy tym mocom, tym dzielnościom tellurycznym? - Kruszec z otchłani, bity i cechowany napisem, czyż nie jest primum mobile i zarazem hamulcem wszystkiego na świecie? Czyż nie ruszył ziemskiej własności i czy jej z rąk do rąk chyżym nie przenosi obiegiem? Czyż nie zmienia wszystkich między ludźmi i narodami stosunków? Czyż nie wprawił w obrót i ruch tego, co by się może nigdy było nie ruszyło z swego miejsca? Ten metal, prędki jak widzenie, przekupił statek [tj. zakłócił spokój-R.G.-S.], zachwiał cnotą, rozpalił wszystkie pożądliwości, uprzątnął wszystkie przeszkody, porównał wszystko z ziemią, z błotem, z którego jest wzięty i oczyszczony; rozczarował wszystkie powaby, rozbił urok wszystkich ponęt; ostudził, oziębił zapał, którego żaden brzęk ani srebrny, ani złoty nie zasili! Rozum mędrców i ludzi stare lata mających podbił pod posłuszeństwo swoje - z nieba daleko w przepaść, w ziemię ich wrzucił. Wyostrzył dowcip, udoskonalił rachmistrzostwo, ale zwojował moc ducha". M. MocHNACKI, O literaturze polskiej w wieku XIX, w: tenże, Rozprawy literackie, oprac. M. Strzyżewski, Wrocław-Warszawa-Kraków 2000, s. 190-191.

Wierzący w ,po dzi emną as trologią”, to jest „związki czarnoksięskie, moralne i chemiczne, w powinowactwo, żadną mocą nie rozerwane, natury anorganicznej z organiczną, w związki i powinowactwa kamieni, metali z istotami rozmyślającymi, a bardziej jeszcze dumają cymi", Mochnacki wprowadził pieniądz (złoto) do antropologii romantycznej (uzasadniała to $\mathrm{m}$. in. teoria powszechnych powinowactw). Ta wczesna romantyczna ,antropologia pieniądza” godna jest uwagi; wiele z uwag polskiego krytyka antycypuje bowiem konstatacje zapisane w młodszej o prawie stulecie Filozofii pieniądza (1900) Georga Simmela (np. o ruchliwości pieniądza i przyspieszeniu tempa życia przezeń wywołanym) oraz symboliczne asocjacje Freuda (wiążącego pieniądz z kałem i błotem). Tekst Mochnackiego stanowi zarazem signum temporis wieku XIX; u Dantego, tym, co „słońce i gwiazdy porusza”, była Boża wszech-miłość - człowiek „,wieku kupieckiego i przemysłowego", odkrywa, że źródłem ruchu świata jest pieniądz. Temat ten będzie jeszcze wielokrotnie powracał w utworach i listach polskich romantyków.

O Mochnackiego krytyce ekonomii zob. L. BIERnACKI, Zabić ministra skarbu, w: Pieniadz w literaturze i teatrze, s. 89-105. 
W swej antykapitalistycznej retoryce romantycy polityczni bardzo przypominają Karola Marksa. Jak z ironią zauważył Ernst Hanisch, różnica między Adamem Müllerem a Marksem polega na tym, iż ten pierwszy nie znał jeszcze pojęcia wartości dodanej ${ }^{3}$. Poza tym mamy do czynienia z samymi podobieństwami: alienacja jednostki i jej pracy, urzeczowienie stosunków międzyludzkich, mechanizacja życia, despotyzm pieniądza, egoizm zysku, sprowadzanie wszystkiego jedynie do wartości ekonomicznej, z życiem ludzkim włącznie ${ }^{4}$.

Dramat bezpośredniego uzależnienia ludzkiego życia od pieniądza, już w jego elementarnym wymiarze: biologicznym, aż po perspektywy rozwoju i spełnienia, stał się także jednym z najpierwszych odkryć wkraczającego z życie, osieroconego Norwida ${ }^{5}$. Problem ten wyraźnie obecny jest w juweniliach poety, na przykład w liryku Sieroty:

Ja widziałem młodzieńca, co w okropnej nędzy

Dniem i nocą pracował, by dostać pieniędzy,

Pieniędzy! które swoim przeważnym ciążeniem

Przytrzymywały jego matkę na tym świecie.

(Sieroty; PWsz I, 5).

Z sierocą dolą i łzami Norwid połączył pieniądz także w satyrycznym młodzieńczym opowiadaniu Łaskawy opiekun, którego tytułowy bohater - pan Drążkowski, nieuczciwy i sprytny „opiekun” Barłomieja Sochy, zagarnia sieroce fundusze podopiecznego (syna swego zmarłego ekonoma), a następnie z pomocą cynicznego wybiegu pozbywa się chłopca z domu:

- Przyjaźń przyjaźnią, a interes interesem - wyrzekł po chwili pan Drążkowski [...]

- [...] Wychowańcze mój, wiesz o tym dobrze, ze dałem ci naukę i wszelakie ciała wygody, chociaż szczupła suma od twych rodziców przeznaczona zupełnie na to nie wystarczyła...

Tu Bartłomiej uczuł się w przykrym położeniu, pułkownik zaś odkaszlnął i zamykając biurko tak dalej zaczął mówić:

- Pieniądze są niczym!... miedź, srebro, złoto, nawet listy zastawne nabyć można z łatwością, ale piękne imię i szlachectwo to są dopiero klejnoty! Synu mój - rzekł opiekun zapalając się niespodzianie - synu mój! ja wyszukałem w papierach twojego ojca, że cała rodzina Sochy szlachtą była od dawna!! (Laskawy opiekun; DW VII, 29-30).

${ }^{3}$ Wartość dodana to w koncepcji Marksa przyrost wartości dóbr w procesie produkcji lub świadczenia usług. Źródłem wartości dodanej jest ludzka praca.

${ }^{4}$ M. A. Cichocki, s. 43.

$5 \mathrm{Na}$ zainteresowanie młodego Cypriana tematem pieniądza mógł też w pewnym stopniu wpłynąć fakt, iż jego ojciec - Jan, parał się rozmaitymi zajęciami związanymi z zarządzaniem majątkiem ziemskim oraz finansami, m. in. był plenipotentem Opieki Masy Radziwiłłowskiej, później zaś pracował w Komisji Biletów Bankowych oraz w Komisji Rządowej Przychodów i Skarbu. 
Laskawy opiekun jest kapitalną, przenikliwą satyrą na pazerność, hipokryzję i materializm, idące w parze z parafiańszczyzną, kalectwem umysłu i serca. Portret Drążkowskiego, kontaminujący cechy obu „łaskawych opiekunów” samego Norwida: znanego z majątkowej zapobiegliwości Ksawerego Dybowskiego (zwanego wymownie „Bogaczem”) i pułkownika Michała Sobieskiego, to molierowskie w swej celności studium chciwości:

Powierzchowność pana Drążkowskiego, zwłaszcza kiedy tenże kontrakt jaki zawiera, nie jest bardzo obiecująca, przy otwieraniu jednakże szkatuły dają się spostrzegać na jego licach skryte jakieś pomysły i pewien rodzaj powolności, która nigdy biegłych strategików nie odstępuje. (DW VII, 16)

[...] zaczął myśleć z zapałem o poprawie losu swego Barłomiejka, do czego jeszcze prócz kobiet zniewalało go także i owe grosiwo, które nieboszczyk Socha wraz z swoim synalem oddał mu w opiekę. (DW VII, 14)

[...] pułkownik tymczasem nie przestał myśleć o jego przyszłości, a ilekroć razy zajrzał do szkatuły i dostrzegł depozyt nieboszczyka Sochy, tym większym jeszcze ogniem podniecał swój zamiar i tym bardziej pragnął wyświadczyć przysługę wychowankowi (Laskawy opiekun, DW VII, 26) ${ }^{6}$.

Młody Norwid bardzo szybko zdał sobie również sprawę z uwikłania twórcy w sidła mechanizmów podaży i popytu. Świadectwem moralnych dylematów i zmagań duszy romantycznej z pokusami sprzedajnego świata jest jego młodzień-

${ }^{6}$ Przedmiotem dialogów prowadzonych przy stole Drążkowskich są wyłącznie „interesa” i „kapitały”, a stałym gościem i towarzyszem pana domu jest kupiec, który zwykł zasypiać trzymając pod poduszką ... woreczek z pieniędzmi:

„Po chwili pan Drążkowski położył książkę na stole, ziewnął, uściskał Edwarda i zadał mu pytanie: „Wiele kosztuje edukacja syna, kiedy dobry ojciec przez lat cztery po sto dukatów corocznie na nią wydaje?"

[...] - Prawda jest, słuszna prawda, przy pracy i uwadze wszystko z siebie uczynić można... Wieluż to ja znam takich, mości dobrodzieju, co w młodości swojej zupełnie nic nie mieli i tylko z łaski żyli, a teraz co za domy! co za kapitały! co za spekulacje!..." (Easkawy opiekun, DW VII, 19).

Temat zagarniania sum sierocych powróci u Norwida (kawalera maltańskiego!) nawet po latach. W roku 1865, w liście do Konstancji Górskiej, do takiej obrabowanej z majątku sieroty porówna poeta Warszawę:

„Jest to wychowanica, sierota z wielkiego rodu, zmieniona na popychadło domowe przez opiekunów raz wraz się przemieniających i doprowadzających dziecię do obłąkania, aby potem w szpitalu wariatów zamknąć, za idiotę ogłosić i nakazać na intencję jej wyzdrowienia oficjalne pacierze, a tymczasem fortuną sieroty podzielić się” (List do K. Górskiej, DW XII, 385). 
cza fantazja zatytułowana Chwila myśli ${ }^{7}$. W tym fragmencie romantycznej biografii (nawiązującym tytułem do Godziny myśli Słowackiego oraz wileńskich Dziadów $c z$. IV Mickiewicza) na plan pierwszy wysuwa się zapis bolesnego i wstrząsającego doświadczenia inicjacyjnego: demaskacja ukrytych, finansowych mechanizmów rzeczywistości oraz bunt przeciw tak posadowionemu światu'

\section{MŁODZIENIEC}

po chwili

Takie to widziadła

Ułomność ludzka przed oczyma kreśli Pieniądz króluje - bogdajby przepadła Jego wszechmocność! a jednakże trzeba, Rozćwiertowawszy godne człeka życie, Sprzedać je na wpół. [...]

Dopóty pisać, aż brzęknie pod piórem Sprzedany wyraz - aż zabrzękną chórem Wszystkie stronice - i głowa, jak mina Ciężarna złotem, wesprze się na ręce.

$[\ldots]$

Pisać więc, pisać i frymarczyć mową, Myśli jak bydło przedać całym stadem, [...] zapomnieć nieba Dla worka groszy. [...]

Potrzeba jeszcze, póki serce żyje, Sprzedać je światu za kilka srebrników!

(Chwila myśli, DW V, 13-14) ${ }^{9}$.

7 Zwraca również uwagę metaforyka „rachunkowości” w pisanym niemal równocześnie z Chwila myśli urywku Dobrzy ludzie:

Często z rozpaczą słucham, jak obecność taje,

Kroplami chwil upada w odmęt zapomnienia,

A człowiek Bóg wie komu życie zaprzedaje,

$[\ldots]$

I szydzi z rozrzutników, co marnują grosze,

A nie wie, że na groszach, tych liczmanach życia,

Nie kruszec, ale troski ważyć, i rozkosze,

I wprawiać się powinien w rachunkowość życia.

(Dobrzy ludzie, DW V, 21).

${ }^{8}$ Stosunek głęboko wierzącego Norwida do kwestii finansowych był od samego początku (i aż do końca) kształtowany przez ,ekonomię biblijną”.

9 Późniejsza nieco Norwidowska Wigilia (1848) przywołuje scenę kuszenia na pustyni opisaną przez św. Mateusza (Mt 4,1-11), w której zły duch nakłania poszczącego Jezusa do zamiany 
W późnych latach 40. już nie tylko własne sieroce doświadczenia i biedy napędzają refleksję Norwida o pieniądzu. Przeżyciem zbiorowym staje się kryzys światowy u progu Wiosny Ludów. Na ten czas przypadła też zapewne Norwidowa lektura pism Proudhona, eseju Qu'est-ce que la propriété? ${ }^{10}$ oraz słynnej Filozofii nędzy ${ }^{11}$ wydanej w roku 1846, które młody poeta musiał znać choćby z ręki Edmunda Chojeckiego, swego bliskiego przyjaciela a zarazem współpracownika i gorliwego wyznawcy tego francuskiego socjalisty-anarchisty. Proudhon postulował rewolucję ekonomiczną opartą na idei darmowego kredytu oraz systemie pomocy wzajemnej ${ }^{12}$. Rewolucyjność jego Filozofii nędzy polegała jednak nie tyl-

kamienia w chleb. Owe szatańskie pokusy dotyczące głodu i posiadania dóbr zyskują tu szatanowi nowe, uwspółcześnione imię: Zysk.

Za odległe gdzieś rzeczy -

Dziś włosienie kaleczy,

A już zorze jedwabią się z dala -

Szatan przybiegł i prawi:

„Oto ogon mam pawi,

Cały z ognia, co słońce zapala.

Przeto - nie pość już więcéj,

Pokarm stracisz zwierzęcy,

Młode Jutro zamorzysz uściskiem..."

- Idź precz, diable, co kamień

Panu dałeś - i ,zamień

W chleb" wołałeś - nazowiesz się Zyskiem.

(Wigilia, DW IV, 336).

Tak więc już Norwidowskie juwenilia i utwory z końca lat 40. odsłaniają diaboliczny charakter pieniądza, jego destrukcyjny wpływ na ludzkie życie (nędzę, pozbawianie człowieka duchowej autonomii, odwodzenie od troski o dobra duchowe i zbawienie). Młody twórca ze zdumiewającą przenikliwością postrzega, że pieniądz zastępuje i wyjaławia inne symbole, nawet samego Boga, imituje religijne doświadczenie Absolutu, umieszcza siebie w centrum. „Zysk” staje się ziemskim bogiem, synonimem imienia szatańskiego.

Niegodzący się z takim porządkiem świata młody Norwid wytyczył sobie drogę niepodległości duchowej. W wierszu Pióro (PWsz I, 49) sformułował manifest twórczości wolnej od jakichkolwiek uwikłań materialno-finansowych i pozostał mu wierny do swej śmierci w przytułku. Nigdy do żadnej ,czapki” klamrą nie przykuł się złotą.

${ }^{10}$ Padło w nim słynne zdanie: „Własność to kradzież”. Zdaniem Proudhona wszelką własność legitymizowała wyłącznie praca.

${ }^{11}$ P. J. Proudhon, System sprzeczności ekonomicznych, czyli filozofia nędzy, w: tenże, Wybór pism, t. I, wstęp J. Garewicz, Warszawa 1974.

12 Zob. np. N. Ferreira, Crédit et monnaie sociale chez P. J. Proudhon (1809-1865), „Revue de philosophie économique" 2011, nr 1 (vol. 12), s. 91-116. 
ko na śmiałości pomysłów finansowych; książka ta przede wszystkim radykalnie zmieniała pozycję nauk ekonomicznych, przyznając im miejsce dawnej metafizyki - „filozofii pierwszej” zwanej też niekiedy „teologią”, a ujmującej byt od strony jego pierwszych, boskich zasad i przyczyn:

$[\ldots]$ nauka ekonomiczna, najczystsza, najbardziej, [...] zrozumiała ze wszystkich nauk, [...] ma charakter postępowy: oto nowa teza, która czyni z tej nauki logikę lub metafizykę in concreto i radykalnie zmienia podstawy dawnej filozofii. Inaczej mówiąc, naukę ekonomii traktuję jako obiektywną formę realizacji metafizyki; jest to metafizyka w działaniu, metafizyka w perspektywie czasu; i ktokolwiek zajmuje się prawami pracy i wymiany - jest naprawdę metafizykiem. [...]

Praca człowieka to dalszy ciąg dzieła Boga, który stwarzając wszystkie istoty, działa poza sferą wiecznych praw rozumu. Nauka ekonomiczna jest więc siłą konieczności, zarazem teorią idei, teologią przyrodzoną i psychologią ${ }^{13}$.

Eksplozja publikacji na temat pieniądza w połowie XIX stulecia była konsekwencją realiów społecznych tamtego czasu. Za życia Norwida miało miejsce aż siedem wielkich załamań rynku światowego, z czego szczególnie dotkliwe były: kryzys u progu Wiosny Ludów (1847), pierwszy kryzys światowy (1857), kryzys po wojnie secesyjnej (1866), najpoważniejszy i najdłuższy kryzys XIX stulecia z roku 1873 (czyli już po powstaniu Vade-mecum) oraz zapoczątkowany we Francji kryzys roku $1882^{14}$. Powracały więc one periodycznie, mniej więcej co 10 lat $^{15}$, stając się zauważalnym i boleśnie odczuwalnym zjawiskiem w rzeczywistości tamtego wieku.

W obliczu powtarzających się kryzysów spowodowanych niedoborami zapasów złota Proudhon zaproponował reformę monetarną połączoną z organizacją kontraktową kredytu bankowego i stowarzyszeniami pracowników w celu osiągnięcia nowej organizacji społeczeństwa. W $1849 \mathrm{r}$. założył „bank wymiany”, który następnie stał się „,bankiem ludu” - uprzywilejowanym instrumentem, który mógł odwrócić stosunek kapitału i pracy dzięki wzajemnemu i nieodpłatnemu kredytowi, zniesieniu waluty (oraz odsetek w pieniądzu i zastąpieniu ich „bonami” lub „,kuponami obrotowymi”) i uogólnieniu weksla.

13 P. J. Proudhon, System sprzeczności ekonomicznych, czyli filozofia nędzy, s. 193-194.

14 Zob. W. Morawski, Kronika kryzysów gospodarczych, Warszawa 2003, s. 55-82.

Kryzys z roku 1873 zrobił na współczesnych szczególnie silne wrażenie. Karol Marks celowo opóźnił prace nad drugim tomem Kapitału, by uwzględnić w nim płynące z tej ekonomicznej katastrofy wnioski.

${ }^{15}$ W XIX wieku wraz z uprzemysłowieniem ukształtował się mechanizm regularnego, trwającego 10-12 lat cyklu koniunkturalnego, obejmującego nie tylko finanse, ale także poszczególne gałęzie produkcji. Ten podstawowy cykl został opisany po raz pierwszy w roku 1862 roku przez francuskiego ekonomistę Clementa Juglara i nosi jego imię. Zob. tamże, s. 10. 
Problem ekonomiczny szczególnie nabrzmiał w latach kształtowania się Norwidowego Vade-mecum, kiedy również sam autor tego poetyckiego cyklu pozostawał w ciężkich tarapatach finansowych (niemożność wydania kunsztownie przygotowanego zbioru potęgowała jeszcze jego materialne udręki). W roku 1866, po wojnie secesyjnej ${ }^{16}$, przez Amerykę i Europę przetoczyła się fala potężnej recesji, uważana za początek końca II Cesarstwa we Francji ${ }^{17}$. To właśnie jej dramatyczne skutki pokazał w pierwszym tomie swego Kapitału Marks ${ }^{18}$ (tom drugi tego dzieła ukazał się po kolejnym kryzysie z lat 70.). Tytułowym bohaterem tego epokowego i wpływowego dzieła stał się pieniądz. W świecie naznaczonym bogactwem kapitalistów i nędzą niepoliczonych rzesz awansował on do roli głównego bohatera koncepcji ekonomicznych oraz teorii polityczno-ustrojowych i społecznych. Kwestia sprawiedliwego podziału zysku stała się jedną z najistotniejszych i najbardziej palących kwestii.

Kapitał stanowi ważny, choć oczywiście bardzo daleki, a nawet biegunowo odległy (w sensie ideowym) i w związku z tym w żaden sposób nie pokrewny, kontekst historyczny Norwidowego Vade-mecum. Uderzająca jest jednak zbieżność czasu powstania obu dzieł: w przypadku Vade-mecum są to lata 1865-66, pierwsza edycja pierwszego tomu Kapitału Marksa przypadła natomiast na rok 1867. Choćby z tego powodu nie sposób nie wspomnieć o niemieckim ekonomiście, czytając Norwidowe opus magnum.

Pierwsza część Kapitału (zwanego przez autora „ekonomicznym paskudztwem"19) została poświęcona drobiazgowej analizie procesu wytwarzania i cyrkulacji towarów oraz ich wymiany na „byt konkretny i brzęczący”20. Ukazywała ona rozwój „formy pieniężnej” i jej „przyrastanie” do artykułów wymiany (innymi słowy to, jak „towar-pieniądz” nabiera wartości użytkowej, jak moneta

${ }^{16}$ Zob. tamże, s. 65-69.

${ }^{17}$ Detonatorem ekonomicznego załamania była jednak, jak twierdzą eksperci, nie tyle wojna secesyjna, co zakończenie kilku konfliktów zbrojnych w Europie. We Francji problemy związane z kryzysem dodatkowo pogłębił nieurodzaj z roku 1867. Francuzi spodziewali się, że do poprawy sytuacji ekonomicznej przyczyni się otwarta w tym samym roku paryska Wystawa Światowa, jej wpływ na koniunkturę okazał się jednak powierzchowny. Prawdziwym ciosem dla Drugiego Cesarstwa i początkiem jego końca okazał się upadek inwestycyjnego banku Credit Mobilier. Jednym ze skutków społeczno-politycznych tego europejskiego kryzysu było wzmocnienie pozycji Pierwszej Międzynarodówki (utworzonej w roku 1864). Zob. tamże.

18 Zob. K. Marks, Das Kapital. Kritik der politischen Ökonomie, Hamburg 1867.

${ }^{19}$ F. WheEn, Marks. Kapitat. Biografia, przeł. P. Laskowski, Warszawa 2007, s. 31.

${ }^{20}$ K. MArks, Kapitat. Krytyka ekonomii politycznej, t. I: Proces wytwarzania kapitatu, przeł. z niem. [brak nazwiska thumacza-R.G.-S.], wyd. 3, Warszawa 1950, s. 117. Pierwsze polskie wydanie Kapitału ukazało się w Lipsku w 1884 roku. 
staje się „znakiem wartości”), a następnie poszczególne stadia cyrkulacji, splot metamorfoz towarów w pieniądz (i odwrotnie) oraz uczestniczące w tym spektaklu dramatis personae (sprzedawcę, pieniądz i nabywcę). Marks zauważał, że podstawową cechą pieniądza jest nieustanny ruch:

W pierwszej połowie swej cyrkulacji towar zamienia się z pieniądzem na miejsca. Dzięki temu jego postać użytkowa przechodzi ze sfery cyrkulacji do sfery konsumpcji. Miejsce jego zajmuje postać jego wartości, czyli jego maska pieniężna. Drugiej połowy cyrkulacji nie odbywa towar w swej własnej skórze, lecz w swej skórze złotej ${ }^{21}$;

[...] cyrkulacja wciąż wydziela pieniądz ${ }^{22}$.

W kolejnych rozdziałach uwagę autora przykuwała masa cyrkulujących pieniędzy i towarów, wzajemna zależność ruchu cen, masy towarów i szybkości obiegu pieniądza (czyli prawa handlu) oraz proces „kamienienia” pieniądza w skarb. Przy okazji tych popartych matematycznymi wyliczeniami analiz padały celne spostrzeżenia o wpływie pieniądza na życie społeczne, o jego zdolności do wdzierania się nawet do sfery duchowej oraz zacierania (niwelowania) granic między sacrum a profanum:

Cyrkulacja staje się olbrzymim tyglem społecznym, do którego wszystko wpada, aby zeń wyjść jako kryształ pieniężny. Alchemii tej oprzeć się nie mogą nawet relikwie świętych a tym mniej subtelniejsze res sacrosanctae, extra commercium homminum [rzeczy uświęcone nie będące przedmiotem handlu]. Podobnie jak wszelkie różnice jakościowe między towarami zacierają się w pieniądzu, tak też pieniądz ze swej strony, jak radykalny leveller, zaciera wszystkie różnice ${ }^{23}$;

$[\ldots]$ pieniądz nie zna granic $[\ldots]^{24}$.

Tym, co najbardziej interesowało Marksa, był sposób przemiany pieniądza w kapitał, powstawanie zysku oraz proces materializacji ludzkiej pracy w towarze (wymienialnym na pieniądz). W ujęciu niemieckiego ekonomisty pieniądz stawał się urzeczywistnieniem ludzkiej pracy in abstracto $^{25}$, sama zdolność do pracy bez możliwości jej sprzedania, spieniężenia traciła natomiast wszelką wartośćc ${ }^{26}$. Autor obnażał w końcu skrzętnie skrywaną tajemnicę powstawania zysku: jego me-

21 Tamże, s. 121.

22 Tamże, s. 119.

23 Tamże, s. 139.

24 Tamże, s. 140.

${ }^{25}$ Zob. tamże, s. 150.

${ }^{26}$ Marks cytował Sismondiego: „Zdolność do pracy jest niczym, jeśli nie zostanie sprzedana”. Tamże, s. 184. 
chanizm sprowadzał do „niezliczonych kradzieży czasu” robotnika ${ }^{27}$. Sugestywnie, choć zarazem niezwykle rzeczowo, pokazywał też proces odczłowieczenia w systemie pracy najemnej. Dopełnieniem teorii były przerażające obrazy wyzysku i nędzy, degeneracji fizycznej i duchowej. Kapitał stawiał przed oczy współczesnych mękę przepracowania i bezrobocia, przedwczesną śmierć, brutalną samowolę kapitalistów, wyrachowanie rentierów i lichwiarzy, spryt „wilków giełdowych"28. Bezlitośnie demaskował mechanizmy formowania się „,nowoczesnej bankokracji” (bankowej finansjery), bez skrupułów wpędzającej kolejne państwa w dług publiczny, by następnie wywierać z pomocą tego narzędzia wpływ na politykę gospodarczą, a nawet kształtować ustrój. Przykłady finansowej drapieżności i zdziczenia skłoniły nawet Marksa do sformułowania ironicznego, parodystycznego przykazania chciwości: „Akumulujcie, akumulujcie! Tak głosi Mojżesz i prorocy!”29.

Marks obnażył prymat rozwiązań ekonomiczno-strukturalnych w społeczeństwie współczesnym, wykazał, że kapitalizm degraduje nie tylko rzeczy, ale i ludzi, sprowadzając ich do rangi towarów (kupowanie czasu pracy robotnika), niszcząc ich godność i szanse realizacji. Towary nazywał „fetyszami”, ubóstwo - „łamaniem ducha ludzkiego”, pomnażanie kapitału - „wywłaszczaniem” człowieka, kapitalizm zaś - „religią zmysłowych żądz”. Jedną z najważniejszych konstatacji było jednak spostrzeżenie, że w systemie gospodarki kapitalistycznej człowiekiem zaczyna rządzić „twór jego własnych rąk”" ${ }^{\text {: }}$ : pieniądz. Kapitat nie był oczywiście wyłącznie studium ekonomicznym; formułował też nową filozofię społeczną.

Koncentracja zbiorowej uwagi ówczesnych społeczeństw i myślicieli na pieniądzu musiała wpłynąć na charakter Vade-mecum. Globalne problemy wieku i osobisty dramat ekonomiczny Norwida odbijają się niczym w zwierciadle w pochodzących z lat 60 . listach poety, w których temat pieniądza, po pierwsze własnego, jest szeroko komentowany:

Tu już zachodzi zwykle kwestia zdrowia - lub kapitału, czyli rzeczy, która dziś, tyle razy ze zdrowiem na niekorzyść, nie zaś na korzyść onego zdrowia - jedno znaczy. A kiedy się to tam odmieni? kiedy?... (List do A. Cieszkowskiego, DW XII, 61);

27 „Zyskiem” stawał się „nadmiar” biorący się z wydłużenia czasu pracy najemników ponad 6 godzin. W ten sposób robotnik stawał się siłą produkującą cudze bogactwo, maszyną do wytwarzania „wartości dodanej”. „Praca ubogiego kopalnią bogacza” - pisał Marks.

28 Tamże, s. 306.

29 Tamże, s. 641.

Za ,grzech pierworodny” ludzkości uważał Marks akumulację pierwotną, czyli pierwsze zgromadzenie bogactw przez wybrane grupy społeczne, które pociągnęło za sobą wieczną nędzę jednych i wzrastające do niebotycznych rozmiarów, nieprzyzwoite wręcz bogactwo innych.

30 Tamże, s. 670. 
Dla nas [...] trzeba, aby człowiek miał zarazem geniusz Horacego, mądrość Solona, talent Salvatora-Rosy, obywatelstwo Cycerona, zdrowie centaura, piękność dyskobola greckiego, anegdoty i pogadanki Radziwiłła Panie Kochanku - i pieniądze, pieniądze bankierskie!! - (List do A. Cieszkowskiego PWsz IX, 164).

Już na początku lat 60. Norwid pisał do Joanny Kuczyńskiej o swych „lichych interesach finansowych" (DW XII,15), utyskując na brak jakiegokolwiek „realnego stanowiska” (DW XII, 21): „bardzo mam wiele ciężarów na biednych siłach moich" (DW XII, 113). Zadłużony u Augusta Cieszkowskiego na około półtora tysiąca franków obiecywał spłatę tej należności w bliżej nieokreślonej przyszłości. Czynił rozpaczliwe projekty zwrotu tego przerastającego jego możliwości kredytu z maleńkiej renty, wypłacanej mu z odsetek od kapitału złożonego w paryskim banku przez jego kuzyna - Michała Kleczkowskiego (PWsz IX, 296). Jednocześnie zalegał 600 franków Joannie Kuczyńskiej („nigdy nie pomnę, abym raptem znalazł się gorzej” List do J. Kuczyńskiej, DW XII, 534). Z pomocą spieszył mu hrabia Ksawery Branicki (List do K. Górskiej, DW XII, 499). Obraz swej rozpaczliwej sytuacji kreślił poeta znajomym i przyjaciołom, zanosząc jednocześnie niemą prośbę o miłosierdzie i pomoc ${ }^{31}$ :

Co do pieniędzy - przy silnych bojach i praca[ch] mam ich ledwo tyle, że poczciwie długi moj[e] opłacam i czasem na rękawiczki starczy (List do J. I. Kraszewskiego, DW XII, 178);

${ }^{31}$ Norwid potrzebował nie tylko środków na życie, ale także niemałych pieniędzy na materiały niezbędne do wykonania zleconych mu prac malarskich bądź medalierskich. Brak pieniędzy opóźniał lub wręcz udaremniał jego przedsięwzięcia artystyczne: „Robię dziesiątą część tego, co mógłbym, i jeszcze nikt o tym nie wie, jak to trudno" (List do A. Cieszkowskiego z 1867 r., PWsz IX, 298-299).

W latach 60. życie Norwida było nieustanną finansową szarpaniną. Poeta miotał się między wierzycielami, zapychając stare zaległości z pomocą nowych kredytów:

„Wczoraj byłem piechotą za Paryżem u jednego małego fabrykanta, u którego miałem dwa moje weksle, i wykupiłem je. Żadnego teraz weksla mojego w obiegu nie ma, ale właśnie dlatego muszę znaleźć kogo, co mi zechce przyjąć nowy weksel na sto pięćdziesiąt franków wypłacalnych po pięćdziesiąt [...]. Za tym biegam i biegam, biegam i biegam, bo od tego zależy nie tylko życie, ale i żywot, z powodu, że roboty czekają, a słoneczne miesiące uchodzą. Oto są grzechy mojego żywota!” (List do A. Cieszkowskiego, PWsz IX, 297-298).

W jednym z paryskich lombardów zastawił złotą szpilkę użyczoną mu przez przyjaciela Bronisława Zaleskiego (prawdopodobnie nigdy później niewykupioną):

„Na końcu tegoż listu znajdziesz słówko, które Ci nadmieni moje finansowe sprawy. Zaszczytną szpilkę zastawiłem za 25 fr.! - skutkiem tego drugiego wekslu mego tą drogą nie wykupię - ale dzięki tej operacji postaram się o znalezienie ku temu środków.

Lecz tym więcej proszę Cię, abyś raczył o zostawionej u Ciebie flaszce próżnej pamiętać, albowiem to, co mam grosza (dzięki Twojej uczynności), muszę jeszcze na atomy rozdzielać, aby wszystkim i wszystkiemu wystarczyć” (List do B. Zaleskiego, PWsz IX, 307). 
Jestem albowiem

$\mathrm{Z}$ rozdartym sercem,

$\mathrm{Z}$ rozdartą kieszenią.

[...] nie mam gorsza (List do M. Sokołowskiego, DW XII, 285);

Dołącz do tego ruinę zupełną w mych interesach finansowych, teatralnych, księgarskich itd. bo wszystko zrujnowano - zostaje mi jeden widok, [...]: cudzoziemski szpital (List do M. Sokołowskiego, DW XII, 323);

Przezierając [...] list Pani, myśliłem o pieniądzach, których często tak mało i tak usilnie nieraz mi potrzeba (List do J. Kuczyńskiej, DW XII, 529);

Złota i srebra nie posiadam - (List do S. E. Koźmiana, DW XII, 418);

[...] jestem goły - klasycznie goły (List do B. Zaleskiego, DW XII, 465).

Rok 1867 był dla Norwida szczególnie dramatyczny. Stracił wówczas jedyne, skromniutkie zabezpieczenie finansowe, jakie posiadał: z powodu śmierci Kornela Kleczkowskiego, która „zatrzęsła” interesami rodziny, kuzyn Michał Kleczkowski cofnął mu wypłatę maleńkiej renty (w wysokości 50 franków) ${ }^{32}$ :

[...] umarł nagle pułkownik Kleczkowski na wyspie Amoy w Chinach i śmierć ta nagła spowodowała położenie czterech osób bez żadnego środka egzystencji... a przeto uczyniła, że małą i jedyną sumkę, jaką miałem sobie zapewnioną u bankiera w Ministerium Spraw Zagranicznych Fr[ancji] utraciłem aż do polepszenia interesów Kleczkowskich, to jest - zapewne na tak długo, że dla mnie na zawsze.

32 Na taką kwotę Norwid wyceniał wówczas jedną swą akwarelę.

Zdruzgotany i upokorzony zwrócił się wówczas z prośbą o wsparcie do swej kuzynki Zofii Radwanowej:

„[...] człowiek, który z nich wszystkich razem właśnie że nigdy nic nie miał i był zawsze żaden -- ten, czy to w Hamburgu, czy w Spa, czy w Chinach co się wydarzy fatalnego, jedyny i ten sam rodzaj następstw zbiera" (List do Z. Radwanowej, PWsz IX, 312).

Skutkiem tej kumulacji dramatycznych przeżyć był nieustępujący przez czternaście dni ból serca. Joannie Kuczyńskiej wyznawał:

,[...] nie mam czasu i mam ledwo ślad miejsca, bo mam normalne i wielkie obowiązki, a żadnego a żadnego stanowiska utwierdzonego realnie.

Słowem:

wszystkie ciężary,

żadnej pomocy [...]"

(List do J. Kuczyńskiej, PWsz IX, 323). 
Czyli że utraciłem wszystko a wszystko, co miałem tu (List do J. Kuczyńskiej, PWsz IX, 318).

Do tych osobistych cierpień dołączyły w latach 60. finansowe utrapienia znajomych poety oraz rodzinne dramaty Norwidów. W roku 1863 na 3 tysiące franków został okradziony brat Cypriana - Ksawery (DW XII, 164). W 1865 śmierć szczerego przyjaciela poety - zbankrutowanego księcia Marcelego Lubomirskiego (przyspieszona przez ,trakasy pieniężne”), postawiła w rozpaczliwej sytuacji wdowę po nim i maleńką córkę (DW XII, 404-405). Rok później (w 1866) głęboko wstrząsnęło Norwidem bankructwo ostatniej osoby, jaka mogła go jeszcze wesprzeć - starszego brata Ludwika, który w ciągu kilku miesięcy przegrał cały majątek żony w salonach gry w Spa i Homburgu ${ }^{33}$ :

Jedyny brat (jakiego mam jeszcze) miał nieszczęście stradać zupełnie cały majątek, to jest około dwakroć-sto tysięcy franków i willę pod Paryżem - następnie zaś zachorzał i cierpi chwile obłąkania [...] (List do J. Kuczyńskiej, PWsz IX, 278);

Miałem wielkie nieszczęście - mój brat, jedyny jaki mi został, stracił cały majątek (List do A. Cieszkowskiego, PWsz IX, 297).

Dramat ten wyrwał z ust Norwida konstatację o tragediowej fatalności ludzkiego położenia - prawdę zobrazowaną wkrótce w dramacie Aktor, którego bohaterem stał się zwiedziony magią hazardu utracjusz:

Żyjemy w Epoce podobnej do piątego aktu tragedii przed nami zaczętej; rób co chcesz, rób co chcesz!... nie odmienisz następstw i losów-aktorów, i pędzących sił do naznaczonego im węzła dramatycznego... fatum... (PWsz IX, 280).

33 Ruina finansowa doszczętnie zniszczyła zdrowie Ludwika: doznał on najpierw chwilowego pomieszania zmysłów, a później wylewu i okresowego paraliżu nóg (zob. List do B. Zaleskiego, PWsz IX, 302). Zakończył życie w przytułku ubogich starców i kalek Warszawskiego Towarzystwa Dobroczynności. Zob. J. W. Gomulicki, Ludwik Norwid, w: Polski Stownik Biograficzny, t. XXIII, Wrocław-Warszawa-Kraków-Gdańsk 1978, s. 201-202; tenże, Zabłąkany pielgrzym. Rzecz o Ludwiku Norwidzie, „Przegląd Współczesny” 1935, nr 163-164, s. 245-258 oraz 391-403; K. BorzęCKA, Ludwik Norwid w świetle poszukiwania miejsca pochówku, „Studia Norwidiana” 34: 2016, s. 155-168; E. Jałochowska, W cieniu sławy. Zapomniane rodzeństwa wielkich Polaków, Warszawa 2018.

Dekadę przed tą katastrofą, nieświadomy jeszcze czekającej go rodzinnej tragedii, Norwid pisał do Kleczkowskiego: „[...] dziś wiele ofiaruje bursa i różny hazard, bo poprzyśpieszane kombinacje samym przyśpieszeniem komunikacji - ale właśnie może dlatego więcej niż kiedykolwiek trzeba znać się i panować nad sobą” (List do M. Kleczkowskiego, DW XI, 239). 
W roku 1867 Norwid dowiedział się jeszcze od Konstancji Górskiej o wysokiej przegranej swego znajomego, hrabiego Ksawerego Branickiego. Zareagował głębokim współczuciem i zrozumieniem:

Jeśli prawda, że p. Ksawery Branicki przegrał tyle w Homburgu, to byłbym bardzo szczęśliwym, gdybym sam miał, bo natychmiast posłałbym mu, prosząc pokornie, aby był łaskaw przyjąć, a gdybym nie miał nadziei, że to bajka i że potrafi sobie dać radę, to sam nic nie mając użyłbym wszystkich moich możności moralnych i nie uchyliłbym się od kroków trudnych i upokarzających, aby tylko zgranemu w Homburgu być uczynnym - albowiem brata miałem w tymże położeniu i, choć sam nie gram, żyłem dosyć na świecie, aby umieć czuć prawdziwie fatalne położenia (List do K. Górskiej z 31 sierpnia 1867, PWsz VII, 304-305).

Owe „fatalne położenia” najbliższych bez wątpienia intensyfikowały „ekonomiczne" przemyślenia Norwida w latach 60., na równi z wielkimi krachami finansowymi, o których donosiła paryska i światowa prasa. O szczególnym zainteresowaniu poety w tamtym kryzysowym czasie tematyką pieniądza (i to nie tylko swym własnym dziurawym budżetem) świadczy drobna, acz ważna wzmianka zawarta w liście do Augusta Cieszkowskiego z 15 lipca 1867 roku:

Secundo: czy p. L. Wołowski załączył Ci mój skrypt sur le Crédit et la Circulation? (PWsz IX, 297).

Tematu tego Norwid nie rozwinął, nie znamy zatem więcej szczegółów, jednak i to pojedyncze zdanie pozwala wyciągnąć daleko idące wnioski. Taki właśnie tytuł: Sur le Crédit et la Circulation [O kredycie i obiegu] nosiła poczytna ekonomiczna rozprawa Augusta Cieszkowskiego, opublikowana po raz pierwszy 22 sierpnia 1840 roku na łamach francuskiego „Journal des Débats”34. Publikacja ta była owocem refleksji polskiego filozofa, wywołanej krachami finansowymi pierwszej połowy XIX wieku. Referowała ona rewolucyjny pomysł zastąpienia pieniądza papierowego („biletu bankowego" wymienialnego a vista na gotówkę) „,biletem rentowym”, który łączyłby zalety „monety brzęczącej” z kruszcu (oraz pieniędzy papierowych) i lokaty; niewydawany, zatrzymany w portfelu, stając się źródłem dochodu dla właściciela. Bilety te miały być emitowane wyłącznie przez państwo ${ }^{35}$, które zabezpieczałoby wypłatę procentu z dochodów publicznych, z hipotek na domenach skarbowych bądź z hipotek gruntowych. Bi-

${ }^{34}$ Doczekała się ona trzech wydań francuskich, trzecie z nich ukazało się w roku 1884, a przekład na język polski wyszedł dopiero w roku 1911 w Poznaniu. Zob. A. CiEszKowski, O kredycie i obiegu, przeł. syn autora, Poznań 1911.

35 Autor zdecydowanie sprzeciwiał się dopuszczaniu banków prywatnych do emisji pieniądza, gdyż otwierałoby to pole do manipulacji instytucjami państwa i do gigantycznych nadużyć. 
let rentowy miał być nowym środkiem obiegowym pozbawionym wad monety oraz biletów bankowych, to znaczy elastycznym, podwójnego użytku (raz monetą - środkiem obiegowym, raz lokatą - kapitałem statycznym) i zarazem bardzo stabilnym, bo znajdującym zawsze pokrycie w masie bogactw narodowych. Chroniłby on banki przed nadmierną ucieczką rezerw (obywatele nie pozbywaliby się go tak chętnie jak zwykłych pieniędzy papierowych) i pozwalałby na naturalną, samorodną regulację rynku (obiegu walorów), nie grożąc nigdy wywołującymi kryzysy skrajnościami.

Drugą zasadniczą kwestią omawianą w rozprawie Cieszkowskiego było „czarodziejstwo kredytu", zwłaszcza globalne klęski wywoływane jego niewłaściwymi, oszukańczymi, dzikimi i pozbawionymi gwarancji bezpieczeństwa formami. Doktor filozofii zwracał uwagę na niedorozwój i wadliwość ówczesnych instytucji kredytowych (twierdził, iż pozostają one wciąż w „fazie niemowlęctwa”) oraz na budzący niepokój fakt, iż kredyt staje się coraz bardziej niematerialny i nieokreślony $^{36}$. Rozprawa obrazowała zgubne dla indywidualnych pożyczkobiorców i całego rynku skutki teorii antycypacji (oraz kredytów konsumpcyjnych), demaskowała wady ówczesnego systemu hipotek i ubezpieczeń. Jednocześnie pokazywała doniosłość organizacji ekonomicznej państwa: „Walory finansowe - pisał Cieszkowski - stanowią krew żywą ciała społecznego, jego żywioł odżywczy i życie rozprowadzający, warunek jego istnienia i rozwoju" ${ }^{\prime 3}$. Metaforą cyrkulacji pieniądza stał się w pracy Cieszkowskiego ożywczy krwiobieg, gwarantujący ciągłość życia biologicznego. Po latach autor podkreślił pokrewieństwo Sur le Crédit... z tematyką swego największego dzieła - Ojcze nasz; wszak modlitewna prośba: „chleba naszego powszedniego daj nam dzisiaj” ściśle wiązała się z zaspokojeniem naturalnych, materialnych potrzeb człowieka ${ }^{38}$.

${ }^{36}$ Niepokój autora budził przede wszystkim fakt, iż kredyty przyznawane były na poczet przyszłych dochodów pożyczkobiorcy i zupełnie nie znajdowały pokrycia w funduszu, aktywach czy nieruchomościach obecnie przez niego posiadanych, innymi słowy, nie opierały się na rękojmiach teraźniejszości, lecz na promesie, antycypowały niepewne dochody przyszłości (,,pożyczki zahipotekowane na zamkach na lodzie"). Drugim powodem do obaw było to, że banki coraz częściej udzielały kredytów nie ze swoich funduszy gwarancyjnych, nie z rezerw, ale z kapitałów nieistniejących (emitowały walory ,,imaginacyjne”), których notabene nigdy klientowi nie wypłacały (Cieszkowski nazwał tę formę „,dyskredytem”). Autor rozprawy uświadamiał też czytelnikom, że kredyt nie stwarza i nie pomnaża kapitału (Ex nihilo nihil fit!), ale jedynie go „odbija”, a nadużycie kredytów prowadzi do porzucenia i zaniedbania realnych zasobów zgromadzonych.

Tematyce ekonomicznej poświęcony był także inny szkic Cieszkowskiego: Uwagi nad obecnym stanem finansów angielskich (1842).

${ }^{37}$ A. Cieszkowski, O kredycie i obiegu, s. 113.

38 Zob. tamże, s. XVI. 
Z cytowanego listu Norwida z roku 1867 wynika, że poeta sporządził na podstawie publikacji Cieszkowskiego jakiś zagubiony dziś „skrypt” (polemiczne uwagi na marginesie, a może nawet własny, konkurencyjny projekt), który przekazał przyjacielowi za pośrednictwem osoby dobrze znanej i w świecie paryskiej finansjery znaczącej, mianowicie Ludwika Wołowskiego, wykładowcy w Conservatoire National des Arts et Métiers ${ }^{39}$ i współzałożyciela paryskiego banku Crédit Foncier de France ${ }^{40}$ - pierwszego w Europie banku kredytów hipotecznych (wzorowanego na Towarzystwie Kredytowym Ziemskim powołanym przez Franciszka Ksawerego Druckiego-Lubeckiego w Królestwie Polskim). Cytowana wyżej epistolarna wzmianka nie tylko wskazuje na żywe zainteresowanie Norwida nowatorskim pomysłem Cieszkowskiego, ale być może potwierdza też osobiste zaangażowanie poety $\mathrm{w}$ ten projekt. Bez wątpienia jest świadectwem jego bezpośrednich kontaktów z najwybitniejszymi reprezentantami kręgów bankierskich Paryża. Jest to ślad istotny o tyle, iż zakorzenia on „ekonomiczne” wypowiedzi i pomysły Norwida w pismach myślicieli i ekonomistów-pragmatyków polskich, a nie wyłącznie zachodnich (których zresztą też wnikliwie czytał). Gdyby natomiast szukać paralel literackich dla interesującej nas tematyki „pieniężnej” w poezji Norwidowskiej, trzeba by bez wątpienia wskazać kasandryczne, wstrząsające diagnozy stawiane zmerkantylizowanemu wiekowi XIX (nieprzypominającemu w niczym wymarzonego przez romantyków ,świata ducha”) przez Zygmunta Krasińskiego ${ }^{41}$ :

\footnotetext{
Wiek mój jest wiekiem bolu - przejścia - nędzy -

Ostatnią walką natury z człowiekiem

Wśród huku machin i brzęku pieniędzy -

I wiek mój dotąd - nie Ducha jest wiekiem!

Na czole jego strach przyszłości leży -

A w piersiach karmi - nie serce - lecz płaza,

Co w krzyż dni przeszłych już dzisiaj nie wierzy

I blednie cały - na widok żelaza!

A w ręku trzyma wór srebra, wór złota
}

39 W 1843 Wołowski objął tam katedrę prawa przemysłowego, a później również ekonomii politycznej.

${ }^{40}$ Bank ten został powołany do istnienia 28 lutego 1852. Drugim jego właścicielem był Ksawery Branicki.

${ }^{41}$ J. W. Gomulicki zwracał też uwagę na ,,piekielne” inspiracje, jakie z dzieł Krasińskiego (Niedokończony poemat) przenikały do twórczości Norwida. Zob. J. W. GomUlicki, Norwidowa podróż przez piekło, s. 8. 
I łokieć kupców, którym przyszłość mierzy,

Marząc, że ona, jako on będzie - z błota! ${ }^{42}$

Konstatacje o budzącym pogardę i przerażenie zawężeniu ludzkich ambicji i marzeń do „podłych chuci” (w czasach, „w których wszystkim ciało”) pojawiają się nie tylko w poezji, ale także w epistolografii i prozie autora Nie-boskiej komedii. Nawet w Albumie sycylijskim, pośród obrazów włoskiej sztuki i czarującej południowej natury, natkniemy się na przywołane tu dla komparacji poruszające obrazy nędzarzy z wielkich europejskich metropolii, takie same, jakie oglądać musiał Norwid i jakie znajdują echo w jego wierszach z Vade-mecum (np. Larwa). Album Krasińskiego przynosi też niezwykle sugestywne zestawienie dwóch typów cywilizacji: pierwotnej, naturalnej, niedopuszczającej całkowitego wykluczenia jednostki, ze stanowiącą wytwór nowych czasów cywilizacją „,kupiecką", której bezduszne, okrutne reguły (awansu bądź eliminacji) dyktuje zimny rozum oraz pieniądz. Zasadą pierwszej z nich jest życie, choć z całą jego nieprzewidywalnością, chaosem i skrajnościami, prawem drugiej - matematyczny ład i idący w parze z nim bezidealizm, egoizm oraz... śmierć:

Wszędzie w ogrodach pomarańczowe, cytrynowe drzewa, na murach aloesy, kaktusy, powietrze takie lube, jakby z innego świata. Lud blady, smagławy, w łachmanach, z płomienistymi oczyma. Żebraków mnóstwo; widok ich nędzy dzikiej znośniejszy jeszcze od wrażenia, jakie wywiera nędza wśród cywilizacji doszłej najwyższego szczebla porządku i samolubstwa. Tu żebracy po błękitem nieba biegną, wyciągają dłonie, wloką się zgarbieni, rzucają się wściekle na rzuconą jałmużnę, ale żaden z nich, jak w Anglii, jak w Londynie, nie usiądzie zgłodniały na ziemi i pisać nie będzie ostatkiem sił na kamieniu: Starvation, come! Widziałem takiego, co czytał taki napis i patrzał na piszącego w jednej z zatraconych ulic Londynu. To okropne, szekspirowskie Starvation, come! to przystanie na śmierć, to wywołanie śmierci z głodu, przyszło mi wczoraj na pamięć, gdym chodził po Mesynie, otoczony żebrzącym ludem, dziećmi na szczudłach, lazzaronami bez nóg i rąk. Oni przynajmniej, choć głód czują, wierzą jeszcze w życie, wierzą, że nie dadzą im umrzeć inni ludzie. Tu zarobek i przemysł nie stał się jeszcze jedynym prawem życia; w Anglii temu, kto pracować nie może, czy z własnej, czy z losu winy, śmierć prawną się stała i wydaje się prawną.

Taka jest różnica między naturą a kupiecką cywilizacją - w pierwszej jest nieporządek, chaos, niepokój, ale zarazem jest życie - w drugiej porządek, rozum, rozgraniczenie i opisanie wszystkiego, ale zarazem egoizm i śmierć bliska ${ }^{43}$.

42 Z. KRASIŃSKI, Wiek mój jest wiekiem bolu-przejścia - nędzy..., w: tenże, Dzieła zebrane, pod red. M. Strzyżewskiego, t. 1: Wiersze, oprac. M. Szargot, Torun 2017, s. 126.

${ }^{43}$ Z. Krasiński, Album sycylijski, w: tenże, Dzieła zebrane, t. III: Proza poetycka, oprac. A. Markuszewska, Toruń 2017, s. 454-455. 
Wizja zachodnioeuropejskiego kapitalizmu jest u Krasińskiego nieprzejednana i dramatyczna; poeta ten, tak Norwidowi bliski i wywierający silny wpływ na jego twórczość, utożsamił merkantylny świat Zachodu wprost z cywilizacją śmierci. Oceny ,wieku kupieckiego i przemysłowego" formułowane przez autora Vade-mecum będą równie druzgocące:

[...] chorobą wieku panteistyczna ekonomia stawszy się, przyćmiła szlachetniejszy wszelki pogląd (List do F. Wężyka z 7 kwietnia 1857, DW XI, 157).

Cała epoka jest małpa sprzedająca wszystko za pieniądze i nikczemna ze wszech miar. (List do K. Górskiej z lipca-sierpnia 1866, DW XII, 524) ${ }^{44}$.

Dzierżący worki z pieniędzmi brzuchaty „kapitalista” trafi nawet do prac plastycznych Norwida jako karykaturalny bohater nowych czasów.

W obliczu powyższych faktów trudno zgodzić się z twierdzeniem Michała Kuziaka, że Norwid nie reagował na kryzysy ekonomiczne kapitalizmu ${ }^{45}$. Przejmujące obrazy uwikłania człowieka w machinacje pieniężne trafiły wszak w latach 60.

${ }^{44}$ Konstancji Górskiej przesłał Norwid takie oto plotkarskie resumé XIX-wiecznej rzeczywistości, sprowadzającej się do towarzyskich banałów i bursy (czyli giełdy) Rotszyldów:

„Anetta [pokojówka Górskiej - R.G.-S.] robi herbatę - Rothschild gra w bursę - pani Franciszkowa Potocka idzie za mąż, pani Kalergi jeździ po bruku warszawskim z kacapem na koźle - ani X. zadrasnęła się w palec szpilką - pan O. zażywa tabakę.

Człowiek jest nicość!"

(List do K. Górskiej, DW XII, 74).

W liście do M. Sokołowskiego wymownie zestawiał wartość słowa bankierskiego i papieskiego:

„Wiele miesięcy temu, kiedy wsiadałem na szczyt omnibusu, uczułem, że mię ktoś za koniec poły targa i woła: „Panie Cyprianie! czy nie pokażesz mi co ? Papież do Ciebie pisał - poszukaj!!” - „Nie mam przy sobie” - odpowiedziałem - i omnibus ruszył po błocie... (ale gdyby to Rotchild albo Rozen pisał!!!!)” (List do M. Sokołowskiego, DW XII, 421). Rotszyldowie byli bankierskimi potentatami Paryża i innych europejskich stolic, Mathias Rozen (1804-1865) - wpływowym bankierem warszawskim, jednym z najbogatszych przedstawicieli tamtejszej burżuazji, współpracownikiem Leopolda Kronenberga w jego przedsięwzięciach tytoniowych i tabacznych. Zob. A. Żor, Kronenberg. Dzieje fortuny, Warszawa 2011; S. KonArski, Rosen (Rozen) Mathias, w: Polski Stownik Biograficzny, t. XXXII, Wrocław 1989-1991, https://www.ipsb.nina.gov.pl/a/biografia/mathias-rosen-rozen?print (dostęp: 15 VIII 2019).

O dominacji pieniądza Norwid pisał raz z powagą i niepokojem myśliciela, innym razem ironicznie lub z humorem ( na przykład gdy w liście do Kuczyńskiej konstatował pojawienie się nowego typu „komerażu”: nowożytnej plotki „,bursowej”, zob. DW XII, 44).

45 Zob. M. KuZIAK, s. 69. 
i 70. na karty jego dramatów ${ }^{46}$. W zelektryzowanej atmosferze wzbierającego kryzysu światowego powstawało także Vade-mecum. Ten opatrzony dantejskim tytułem mistrzowski cykl poetycki można nawet uznać za kulminację Norwidowskiej refleksji o pieniądzu. Kumulacja podejmujących „finansowy” temat liryków (trzeci w cyklu wiersz Socjalizm, trzynasty - Larwa, dziewiętnasty - Stolica oraz trzydziesty siódmy - Syberie) w pierwszej części zbioru świadczy o randze tego zagadnienia w dojrzałej poezji Norwidowskiej. Temat pieniądza zderza się tu z najgłośniejszymi teoriami ekonomiczno-socjalnymi stulecia.

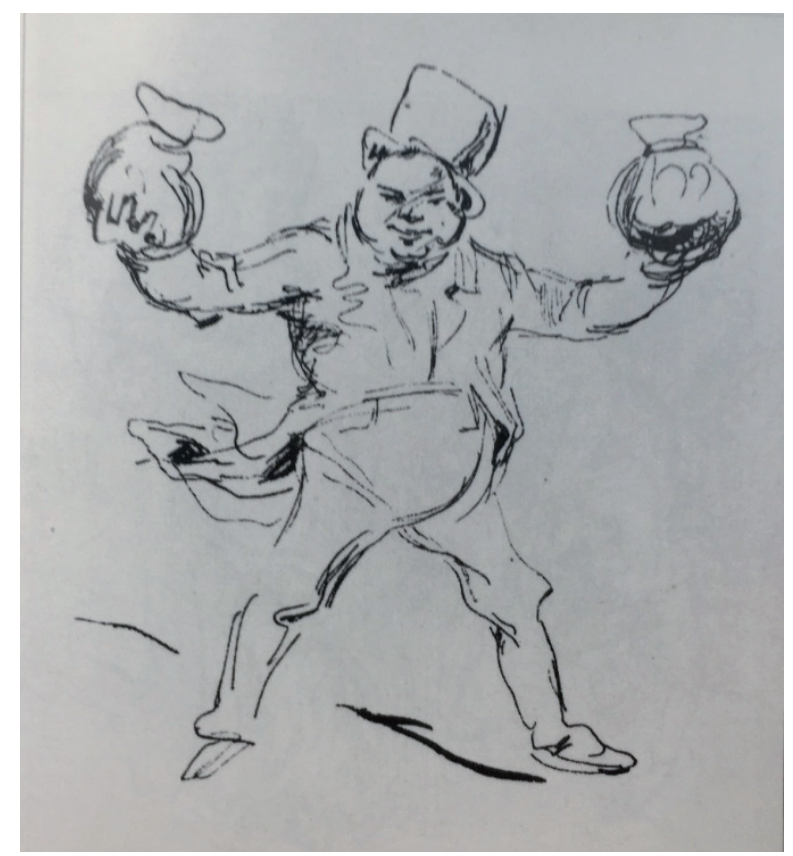

Rys. C. Norwid, Kapitalista, rys. piórkiem i tuszem, Biblioteka Polska, Towarzystwo Historyczno-Literackie w Paryżu, źródło: A. MeLbechowska-Luty, Sztukmistrz. Twórczość artystyczna i myśl o sztuce Cypriana Norwida, Warszawa 2001, s. 473

Nie bez znaczenia dla interesującego nas zagadnienia pozostaje fakt, że w przeciwieństwie do juweniliów (i generalnie literatury wczesnoromantycznej) Vade-mecum jest poezją miasta, wielkomiejskich aglomeracji, takich jak Londyn;

46 Zob. R. Gadamska-Serafin, Pieniadz - ,deus ex machina” w dramatach Norwida, w: Norwidowski świat rzeczy, pod red. G. Halkiewicz-Sojak, P. Abriszewskiej, I. Dobrzenieckiej, D. Wojtasińskiej, Toruń 2018, s. 349-390. 
„za bogactwy goniący we dwa miliony śmiertelnych” Paryż czy Nowy York ${ }^{47}$. Już u zarania procesu urbanizacji miasto było podstawową przestrzenią kształtowania się gospodarki pieniężnej (Londyn nazywano „sakiewką Anglii”), siedzibą handlu (a później także giełdy), miejscem ożywienia gospodarczego i gorączkowej ruchliwości. Jak podkreślał Georg Simmel, to właśnie w mieście wpływ finansów na stan życia psychicznego człowieka stawał się najwidoczniejszy, tu następowała koncentracja obrotu pieniądzem, a szybkość tej cyrkulacji zauważalnie podnosiła tempo życia (inaczej niż w kulturze agrarnej, gdzie cyrkulacja ziemią jest długotrwała, powolna i nie narzuca nadmiernej ruchliwości) ${ }^{48}$. Ów ,ruch zwielokrotniony" i wielkomiejskie tętno wyczuwalne są w strofach Norwidowskich liryków, co zwiastuje, jak zauważa Marta Gaściewicz, poezję nowoczesną ${ }^{49}$.

Michał Kuziak podkreślał podobieństwo tematyczne i stylistyczne publikacji Marksa i Norwida ${ }^{50}$ :

Łączą owych twórców, w sposób często zaskakujący, obserwacje i diagnozy otaczającej rzeczywistości. Niejednokrotnie także przedmiot refleksji [...], a ponadto jej styl [...]. Łączy nastawienie na czyn, syntezę myśli i działania, pracę, również krytyka filozofii idealistycznej,

47 „Poetą miasta” nazwała Norwida Z. Stefanowska:

„Jest Norwid poetą miasta. Jest nim nie tylko w tym znaczeniu, że miasto czyni często tematem swojej poetyckiej refleksji [...]. Chodzi o sprawę bardziej istotną niż tematyka utworów literackich - o to, że zurbanizowana jest wizja świata w poezji Norwida [...]. Miasto jest naturalnym miejscem działalności ludzkiej i tłem sytuacyjnym refleksji poetyckiej. Wieś to coś egzotycznego i zewnętrznego, rekreacyjny margines normalnego życia, „w-czasów królowa” wyjęta spod działania historii. Norwid marzył o ,jednej chwili spoczynku na trawie polskiej” [list do Jana Koźmiana z października 1852 r. - M. G.], i ta tęsknota charakterystyczna jest dla człowieka dobrze wrośniętego w wielkomiejskie środowisko, dla poety, w którego wierszach rozbrzmiewa bruk tylu europejskich miast". Z. STEFANOwsKa, Norwidowski romantyzm, w: taż, Strona romantyków. Studia o Norwidzie, Lublin 1993, s. 79-80.

Zob. też: W. RzońcA, Norwid a romantyzm polski, Warszawa 2005; M. KUZIAK, Romantyzm i nowoczesność?, w: Romantyzm i nowoczesność, pod red. M. Kuziaka, Kraków 2009, s. 12; P. Chlebowski, O sytuacji w badaniach nad Norwidem. Preliminaria, w: Jak czytać Norwida. Postawy badawcze, metody, weryfikacje, pod red. B. Kuczery-Chachulskiej, J. Trzcionki, Warszawa 2008, s. 51-73; S. RZEPCZYŃski, Norwid a nowoczesność, w: Romantyzm i nowoczesność, s. 214-215; M. GARŚCIEwICZ, Piekielna przestrzeń miasta - liryka Cypriana Norwida w perspektywie badań nad nowoczesnościa, http://biesiada.polon.uw.edu.pl/Piekielna.pdf (dostęp: 15.04.2019).

48 Zob. G. SimMel, s. 575.

49 Zob. M. GAŚCIEwICZ, Piekielna przestrzeń miasta - liryka Cypriana Norwida w perspektywie badań nad nowoczesnościa.

${ }^{50}$ Zob. M. KuZIAK, Norwid-Marks. Dwie nowoczesności, w: O Norwidzie komparatystycznie, pod red. M. Siwiec, Kraków 2019, s. 59-75. 
zainteresowanie historią. [...]. Łączy ich, last but not least, wizja pełni pojednanego ze sobą i światem, również społeczeństwem, człowieczeństwa ${ }^{51}$.

Zewnętrznych podobieństw rzeczywiście można dostrzec całkiem sporo. Ciekawym punktem stycznym jest na przykład zakorzenienie obu tekstów w Boskiej Komedii Dantego. Norwidowski zbiór, już samym tytułem zdradzający zapośredniczenie we florenckim arcydziele, zaprojektowany został jako wędrówka po piekle współczesności (,alegoryczna podróż poety-moralisty po piekle stworzonym na ziemi przez ludzi i dla ludzi" 52 - pisał J. W. Gomulicki). Podobny zamysł przyświecał Kapitałowi, który w epoce nędzy proletariatu, ekspansji spektakularnych bankructw, krachów i dzikiej paniki giełdowej obnażać miał infernalny charakter kapitalizmu. Sparafrazowany cytat z Dantego puentował przedmowę do pierwszego wydania dzieła Marksa (notabene żywiącego nawet w młodości ambicje literackie i żywo literaturą zainteresowanego ${ }^{53}$ ):

${ }^{51}$ Tamże, s. 59-60.

Spostrzeżenie to potwierdza, jak się wydaje, szerszą prawidłowość sformułowaną przez Marka Cichockiego: że w swej ,,antykapitalistycznej retoryce romantycy polityczni bardzo przypominają Karola Marksa”. M. A. CiсHоскI, s. 43.

52 J. W. Gomulicki, Uwagi o poezji Cypriana Norwida, w: C. Norwid, Pisma wybrane, Warszawa 1968, s. 31.

Norwid, jak wiadomo, widział potrzebę dopełnienia Dantejskiej summy rozgrywającej się w sferach eschatologicznych: Piekle, Czyśćcu i Niebie, o dziedzinę doczesną: Ziemię, o czym świadczy jego poetyckie pendant do Boskiej Komedii - nieukończony poemat Ziemia (DW III, 51-56).

O Norwidowym ,pobycie w piekle" i literackim (poetyckim i listownym) echu tego doświadczenia pisał J. W. Gomulicki. Zob. tenże, Norwidowa podróż przez piekło (Ze studiów nad geneza ksztaltem ,Vade-mecum”), „Miesięcznik Literacki” 1966, nr 2, s. 5-14. Norwidolog ten uważał Vade-mecum za artystyczną kulminację Norwidowego „mitu piekielnego”:

„Wielkiej zaiste odwagi potrzeba, by uwidamiać i uwieczniać wspótczesne i potoczne momenta-mówił Norwid w r. 1860, w jednym ze swoich wykładów o Słowackim.

Otóż taka właśnie odwaga, odwaga poety-moralisty niechcącego usypiać swoich współczesnych zapewnieniami, że wszystko pięknie, ale pragnącego właśnie budzić ich, wskazując im zło, jakie ich otacza, i cierpienie, jakie jest jego następstwem - pozwoliła mu skomponować Vade-mecum, realistyczny, ale jakże tragiczny obraz moralny dziewiętnastowiecznego społeczeństwa, czy raczej ówczesnego Piekła społecznego, na którego bramach wypisane były hasła Postępu". Tamże, s. 13-14.

${ }^{53}$ Zob. F. WheEn, s. 72-73. Marks odwoływał się do dzieł Szekspira, Dickensa, Thackeraya, Moliera, Racine'a, Montaigne'a, Bacona, Goethego, Woltera, Paine'a, czytał w kilku języka. Pierwszy tom jego Kapitatu zawiera cytaty z biblii, Szekspira, Goethego, Miltona, Woltera, Homera, Balzaca, Dantego, Schillera, Sofoklesa, Platona, Tukidydesa, Ksenofonta, Defoe, Cervantesa, Drydena, Heinego, Wergiliusza, Juwenalisa, Horacego, More'a, Butlera i innych. 
[...] wobec przesądów tak zwanej opinii publicznej, której nigdy nie czyniłem ustępstw, hasłem moim pozostają nadal słowa wielkiego Florentczyka [Dantego - R.G.-S.]:

Segui il tuo corso, e lascia dir le genti! [Idź swoją drogą, a ludzie niech mówią, co chcą R.G.-S.] $]^{54}$.

Dantejska reminiscencja (arcyczytelna też w zbiorze Norwida) sugerowała całkowitą niezależność piszącego od opinii publicznej i zarazem wprowadzała fundamentalną dla kompozycji Boskiej Komedii konwencję wędrówki z autorem poprzez bolączki współczesności (proponując czytelnikowi zupełnie nową drogę). Ów florencki cytat sprawił, że późniejsi biografowie Marksa widzieli w nim nowego Dantego, a w jego traktującym o alienacji, dialektyce i znaczeniu pieniądza Kapitale - rodzaj nowożytnej, odpowiadającej problemom współczesności, ,summy” o człowieku i stworzonej przezeń cywilizacji ,pieniężnej”. Francis Wheen pisat:

Jesteśmy [...] w ziemskim piekle, swoistej świeckiej wersji Piekła Dantego. „Co za różnica, co też tu się gada” - pyta Dantego Wergiliusz w piątej części Czyśćca; - „Chodźże już za mną, niechaj szepczą duchy” (,Vien retro a me, e lascia dir le genti”). Nie mając Wergiliusza, który by go prowadził, Marks poprawia ten wers we wstępie do pierwszego tomu Kapitału, by ostrzec, że nie poczyni żadnego ustępstwa na rzecz cudzych przesądów [...]. Od początku zatem książka pomyślana jest jako zstąpienie do piekieł, i nawet pośród zawiłych teoretycznych i abstrakcyjnych kwestii Marks nie rezygnuje z obrazowania tego miejsca i ruchu [...].

Marks, czyniąc postępy na swej drodze, przywołuje nieraz wcześniejsze, literackie obrazy takich podróży. Opisując angielską manufakturę zapałczaną, w której połowę robotników stanowili młodociani (wśród nich sześciolatkowie), konstatuje:

Dzień roboczy, wynoszący po 12, 14 i 15 godzin na dobę, praca nocna, przerwy na posiłek nieregularne i spędzane przeważnie w tych samych lokalach fabrycznych zapowietrzonych fosforem. Dante przekonałby się, że manufaktura ta przewyższała jego najstraszliwsze fantazje o piekle.

Inne wyobrażone piekła służą wyostrzeniu obrazu empirycznej rzeczywistości:

Z wielobarwnego tłumu robotników wszelkiego zawodu, wieku i płci, osaczających nas natarczywiej niż cienie zabitych osaczały Odyseusza, przy czym na pierwsze wejrzenie można po nich poznać przepracowanie, [...] z tłumu tego wybieramy dwie postacie, modniarkę $i$ ko-

${ }^{54}$ K. Marks, Kapitał. Krytyka ekonomii politycznej, t. I: Proces wytwarzania kapitatu, s. 7. 
wala. Uderzające podobieństwo między obu tymi postaciami świadczy, że w obliczu kapitału wszyscy są sobie równi ${ }^{55}$.

Nowym Dantem czynił się wyraźnie także Norwid (do Joanny Kuczyńskiej pisał w 1862 roku: „Ja - byłem w Piekle, mówiłem raz Pani o tym”, DW XII, 63). Również w jego Vade-mecum ,figurą” nowej cywilizacji jest ,zysk”.

Kapitat i Vade-mecum mają jeszcze jedną cechę wspólną: w obu tekstach niezwykle ważną rolę odgrywa ironia (choć różniąca się głębią i ,techniką” u obu autorów):

Żeby oddać sprawiedliwość obłędnej logice kapitalizmu, tekst Marksa nasycony jest ironią ironią, która wszakże umykała uwadze większości badaczy przez ostatnie 140 lat. Wyjątkiem jest amerykański krytyk Edmund Wilson, który pisał w książce To the Finland Station: a study in the writing and acting of history (1940), że sens Marksistowskich abstrakcji - tańca towarów, błazeńskiego haftu wartości, jest przede wszystkim ironiczny, zyskują one wyraz przez zestawienie z posępnymi, świetnie udokumentowanymi obrazami nędzy i brudu stworzonymi w praktyce przez prawa kapitalizmu.

Wilson widział w Kapitale parodię klasycznej ekonomii i „kiedy go przeczytamy, konwencjonalne dzieła ekonomiczne nie będą już wyglądały tak samo: odtąd już zawsze będziemy mogli dostrzec za argumentami i statystykami surową rzeczywistość ludzkich relacji, którą owe dzieła mniej lub bardziej świadomie maskują". Nikt nigdy nie wniknął głębiej w nieskończoną zdolność człowieka do pozostawania nieświadomym lub obojętnym na ból, który zadajemy innym, gdy tylko mamy szanse uzyskania od nich czegoś dla siebie. „Zajmując się tym tematem, Karol Marks stał się jednym z wielkich mistrzów satyry. [...] jest z pewnością największym ironistą od czasu Swifta i bardzo wiele ma z nim wspólnego ${ }^{56}$.

Specyficzny styl dzieła Marksa, pełen „wymyślnych metafor”, „metafizyki” oraz dygresji i wywodów filozoficznych budził zdumienie ekonomistów, przywyk-

${ }^{55}$ F. WheEn, Marks. Kapitat. Biografia, s. 70-71.

Marks zręcznie wyłowił z Boskiej Komedii metaforykę pieniężną. Przypomniał scenę rozmowy św. Piotra z Dantem (w rozdziale Pieniądz, czyli cyrkulacja towarów), podczas której Florentczyk zgrabnie wyrecytował Apostołowi artykuł wiary, na co ten odpowiedział:

„Assai bene è trascorsa,

D'esta moneta già la lega el peso

Ma dimmi se tu l'hai a tua borsa".

[Dobrze ci poszło z pieniądza tego próbą i wagą;

Ale powiedz no, czy go istotnie masz w swej kiesie].

Zob. K. Marks, Kapitat, t. 1, s. 109.

${ }^{56}$ F. WheEN, s. 74-75. 
łych do suchych, logicznych, popartych wyliczeniami wywodów. W efekcie uznano Kapitat za wielką metaforę współczesności:

Co zatem łączy ironiczny dyskurs Marksa z jego „metafizycznym” ujęciem społeczeństwa burżuazyjnego? [...] Gdyby Marks chciał napisać bezpośredni, klasyczny tekst ekonomiczny, mógłby to zrobić i w istocie zrobił [mowa o wykładach Praca, cena i zysk-R.G.-S]. [...] czyżby Marks nagle stracił dar jasnego mówienia? [...]

Zadaniem metafory jest sprawić, żebyśmy spojrzeli na jakąś rzecz na nowo. Odbywa się to przez przeniesienie wartości tej rzeczy na coś innego, przez zamianę znanego w obce, lub na odwrót. Ludovico Silva, amerykański interpretator Marksa, wychodzi od etymologii słowa „metafora” - przeniesienie - i argumentuje, że kapitalizm sam w sobie jest metaforą, alienującym procesem, który przenosi życie z podmiotu na przedmiot, z wartości użytkowej na wartość wymienną, z tego, co ludzkie, na to, co monstrualne. Przy takim odczytaniu literacki styl, który Marks przyjął w Kapitale, [...] jest jedynym odpowiednim językiem, by ująć „złudne pozory rzeczy". Przedsięwzięciem ontologicznym, którego nie da się zamknąć w granicach i konwencjach istniejących form - takich jak ekonomia polityczna, nauki antropologiczne czy historia. Krótko mówiąc, Kapitat jest całkowicie sui generis ${ }^{57}$.

Genialną metaforą współczesności, całkowicie sui generis, jest też ironiczne Vade-mecum ogniskujące w uderzająco pięknych, wzniosło-gorzkich strofach wszystkie palące problemy człowieka „wieku kupieckiego i przemysłowego”. Oczywiście w tamtym stuleciu Marks był myślicielem nieporównywalnie bardziej wpływowym niż niewydawany (na ogół) i mało słuchany przez współczesnych Norwid.

Jak zauważył Juliusz W. Gomulicki, a za nim Michał Kuziak ${ }^{58}$, „Marks znał [...] ze słyszenia nazwisko Norwida, wymieniane na niektórych mityngach londyńskich" (Metryki i objaśnienia PWsz VII, 653). Dzieła Marksa były z kolei czytane przez Norwida - świadczą o tym jego wzmianki o „ogromnej socjalnej Rewolucji”, która „pierwej w Niemczech doszła do scjentyficznego urobienia” zawarte w rozprawie Nihilizm i nihiliści (PWsz VII, 104) z końca lat 70. (prawdopodobnie z roku 1879), zdradzającej żywe zainteresowanie tematem socjalizmu i anarchizmu oraz programem europejskiej lewicy „osadzonym „na rozwłaszczeniu i ateizmie" (PWsz VII, 103). Wypowiedzi te sygnalizują jednocześnie radykalną odmienność zapatrywań polskiego poety na kwestie socjalne oraz jego jednoznacznie negatywny stosunek do ówczesnej polityki lewicowej: „są fatalną-lewicą”, „to ze zbrodnią graniczy”, „dzieckiem być potrzeba, aby

${ }^{57}$ Tamże, s. 78-79.

${ }_{58}$ Zob. M. KuZIAK, s. 59. O Norwidzie Marks musiał usłyszeć w roku 1875 podczas przemówienia generała Walerego Wróblewskiego, w którym padało nazwisko Norwida, a które było polemiczne wobec poglądów poety. 
w to wszystko wierzyć!” (jednocześnie jednak Norwid był przekonany, że „Rewolucji tej wielkiej nic nie zatrzyma"). Norwidowa rozprawa o nihilizmie oraz dziesiątki innych, także poetyckich, wypowiedzi nie pozostawiają najmniejszych wątpliwości, że na wskazanych wyżej zbieżnościach zewnętrznych jakiekolwiek pokrewieństwo Vade-mecum i Kapitału się kończy. W rzeczy samej proponują one dwie całkowicie odmienne wizje nowoczesności ${ }^{59}$, inne wizje człowieka i inne spojrzenie na istotę problemów ekonomicznych.

Należy przy tym podkreślić, że Norwid nigdy nie uważał tematu finansów za nieważny bądź wstydliwy albo, co gorsza, poezji niegodny (,Są, którzy uczą, iż dla poezji trzeba przedmiotów, które nie byłyby suche i niewdzięczne... Poezja ta - co, ażeby była poezją, potrzebuje przedmiotów niesuchych i czeka na wdzięczne - nie należy do mojej kompetencji” Rzecz o wolności słowa, DW IV, 211). Przeciwnie, stawiał go w rzędzie zasadniczych pytań o człowieka i Prawdę, uznawał za warunek życiowego „Serio" ${ }^{60}$ :

Ani jednego nie ma [pisma polskiego - R.G-S.], które by [...] zapytało przynajmniej - co jest człowiek? co jest życie? co jest czas? co jest praca? co jest pieniądz? co jest wyższość? co jest ład? co jest jawność - - - zatracają Serio!! [...]

Co prawdą jest - jest nią w obrocie planet na niebiesiech i w ziarnku piasku, i w sercu, $i$ w kieszeni, $i$ wszędzie - inaczej, to żarty! (List do M. Sokołowskiego, DW XII, 193-194).

Wątki „ekonomiczno-kapitalistyczne” pojawiają sie w Norwidowskim cyklu nie tylko w wymienionych na początku, czterech zwykle kojarzonych z tym tematem utworach; przewijają się również w różnych innych lirykach. Bez najmniejszej przesady można stwierdzić, iż pieniądz jest w całym zbiorze jedną z najsilniejszych „namiętności czasowych” (Addio!, PWsz II, 23), uosabiających motywowane jedynie czystą ,energią” działanie, nagą ,czynność” i „energię”, pozbawioną jednakże „myśli”, a zwłaszcza „Prawdy” i „sumienia”. Sytuuje się po tej samej stronie, co „Popularność” i „Rozwrzaskliwe czasów przechwałki” (PWsz, II, 100), „strawność dobra” i „byt zdrowy” (PWsz II, 106), a nade wszystko roztaczający złudny czar „sukces” (PWsz II, 122). Skutecznie zapełnia współczesną ,próżnię-sensu”, pozwalając być ,podłym praktycznie” (PWsz II, 99). Niekiedy pojawia się w kontekstach zupełnie zaskakujących, jak na przykład w traktującym o istocie poezji wierszu Liryka i druk, gdzie konieczność współobecności „liry” i „tre-

59 Zob. M. KuZIAK, Norwid-Marks.

60 Milczenie o ekonomicznych uwarunkowaniach ludzkiego bytu i finansowych problemach bliźnich uważał za przejaw hipokryzji, faryzejstwo, przejaw ucieczki od odpowiedzialności za drugiego człowieka. 
ści” w poezji objaśniona została parabolicznie z pomocą egzemplum zaczerpniętego z radykalnie, zdawałoby się, od literatury oddalonego pola kupieckiego:

Handlarz także odda grosz zwierzony,

Lecz nie odda wesela -

Nie uściśnie ręki zawściągnionej;

Maszże w nim przyjaciela?

(Liryka i druk, PWsz II, 24-25).

Wypowiadanie „treści” bez udziału „liry” (a więc talentu, natchnienia, wartości artystycznych, porządku rytmicznego i muzycznego, nieuchwytnych i niewerbalizowanych jakości duchowych) przyrównane zostało do zwrotu powierzonej gotówki, do bezdusznej i przewidywalnej transakcji finansowej, której nie towarzyszy ani ,żar słowa”, ani „sumienia berło”:

[...] To tylko ciało ciału.

Cóż z tego? - martwość głucha!!!

(Liryka i druk, PWsz II, 24).

Ów sugestywny obraz z Norwidowskiej strofy przywodzi na myśl często cytowany w wieku XIX fragment... Manifestu komunistycznego (z roku 1848):

Burżuazja (...) zburzyła wszystkie feudalne, patriarchalne, idylliczne stosunki [...] i nie pozostawiła między ludźmi żadnej innej więzi prócz nagiego interesu, prócz z wyzutej z wszelkiego sentymentu ,zapłaty gotówką”. Świątobliwe dreszcze pobożnej egzaltacji, rycerskiego zapału [...] zatopiła w lodowatej wodzie egoistycznego wyrachowania ${ }^{61}$.

Środka zaradczego na ów dramat europejskich społeczeństw szukali między innymi socjaliści utopijni. Jeden z nich - Robert Owen lokował przyczynę stanu rzeczy w pieniądzu kruszcowym, twierdząc, że jest go na rynku zbyt mało w stosunku do bogactwa ludności (toteż niektórym go po prostu zabraknie) $)^{62}$. Upatrując zła w samym pieniądzu i procesie jego społecznej dystrybucji, to jest w niewłaściwym i niesprawiedliwym mechanizmie gospodarczym, zaproponował, by odesłać ów tradycyjny środek płatniczy do lamusa i zastąpić go bonem, poświadczającym ilość wykonanej pracy i uprawniającym do zakupu towarów o równo-

${ }^{61}$ K. Marks, F. Engels, Manifest komunistyczny, Londyn 1848, https://www.marxists.org/polski/marks-engels/1848/manifest.htm (dostęp: 15.08.2019).

${ }^{62}$ Pomysł Owena upadł, gdyż sztuczny ,pieniądz pracy” nie był w stanie konkurować z istniejącym pieniądzem realnym. 
ważnej wartości. Awersja socjalistów do pieniądza miała zarówno uzasadnienie historyczne (hiperinflacja i bankructwo papierowego pieniądza w czasach rewolucji francuskiej), jak i ideowe:

Socjalizm znalazł podziwiany ideał $\mathrm{w}$ społeczeństwach pierwotnych, $\mathrm{z}$ ich komunistycznym zrównaniem, natomiast pieniądz koncentruje się wokół indywiduum $[\ldots]^{63}$.

Szlachetne, choć naiwne (nawet z punktu widzenia ekonomicznego!) koncepcje socjalistów ${ }^{64}$ zabrzmiały echem w Norwidowskim wierszu Czasy, który po drobnych przeróbkach, opatrzony nowym tytułem: Socjalizm, został włączony do Vade-mecum. Liryk Norwida podważał socjalistyczną utopię bezpieniężnego i dostatniego „końca historii”:

Ludzie, choć kształtem r a s napiętnowani,

$\mathrm{Z}$ wykrzywianymi różną $\mathrm{m}$ o w ą wargi,

Głoszą: że oto źli już i w y b r a n i,

Że już h o s a nn a tylko, albo skargi...

- Że Pyton-stary zrzucon do otchłani:

Grosz? - że symbolem już; harmonią?... - targi!

Och! nie skończona jeszcze Dziejów praca -

Jak bryły w górę ciągnięcie ramieniem;

Umknij - a już ci znów na piersi wraca,

Przysiądź - a głowę zetrze ci brzemieniem...

- O! nie skończona jeszcze Dziejów praca,

Nie-prze-palony jeszcze glob, Sumieniem!

(PWsz II, 19).

\section{Antoni Chojnacki nakreślił szeroki kontekst historyczny tego Norwidowego wiersza:}

W roku 1848 dokonał się sąd ostateczny (dla wielu), który historycy nazwą Wiosną Ludów. W lutym naród francuski obala „króla bankierów” Ludwika Filipa i proklamuje republikę. Do rządu wchodzi socjalista Louis Blanc. Wydawać się może, iż rewolucja socjalna zwycięża, że zwycięża także socjalizm, o który we Francji walczyli od początku wieku Saint-Simon, Charles Fourier, Pierre Leroux, Joseph Proudhon i wielu innych. W marcu wybucha powstanie ludowe najpierw w Wiedniu, a zaraz potem w Berlinie, Mediolanie, Wenecji, Piemoncie, Rzy-

${ }^{63}$ G. Simmel, s. 391.

${ }^{64}$ Pozbyć się pieniądza chcieli nie tylko socjaliści, ale także wielu innych myślicieli, reformatorów i ekonomistów XIX wieku. Zastąpienie tradycyjnego pieniądza „,bonem rentowym” proponował też przywoływany już A. Cieszkowski. 
mie... Rewolucja ogarnia niemal całą Europę: od granic Anglii na Zachodzie, po granice Rosji na wschodzie.

W pierwszej strofie Norwid charakteryzuje [...] poglądy tych utopijnych socjalistów, którzy, upojeni zwycięstwem politycznym, sądzili, że nastąpiła epoka harmonii społecznej, że Europa jest już po sądzie ostatecznym, a zatem, że burżuazja z proletariatem będzie teraz w harmonii budować nowe społeczeństwo ${ }^{65}$.

Norwid wiedział, że nie ma immanentnej etyki pieniądza, że pieniądz, sam w sobie, jest przedmiotem aksjologicznie neutralnym, podobnie jak każde inne narzędzie. Istnieje natomiast etyka ludzkiego zachowania. Stanowisko to wyrasta wprost z myśli chrześcijańskiej, w której bogactwo samo w sobie nie jest czymś dobrym albo złym ${ }^{66}$. Święty Klemens Aleksandryjski pisał:

Nie należy zatem winić tego, co samo w sobie będąc bez winy nie jest ani złe, ani dobre. Winę trzeba przypisywać tylko temu, kto może posłużyć się narzędziem tak źle, jak i dobrze, zgodnie ze swoja wolą. A zdolność tę posiada jedynie rozum ludzki, który może swobodnie osądzać i ma pełną władzę posługiwania się rzeczami użyczonymi człowiekowi. Tak więc nie mienie niszczyć należy, ale raczej namiętności duszy, które nie pozwalają, byśmy w sposób właściwy posługiwali się tym, co posiadamy. A w ten sposób, stawszy się człowiekiem szlachetnym, będziesz umiał posługiwać się właściwie swoim mieniem ${ }^{67}$.

Błąd kierujących się skądinąd szlachetnymi pobudkami socjalistów polegał, zdaniem Norwida, na przypisaniu ontologicznego zła przedmiotowi aksjologicznie neutralnemu, nie zaś ludzkiej woli i duszy, w której owo zło się zakorzenia. Nie brak pieniędzy czy innych instrumentów ekonomicznych był przyczyną nędzy społeczeństw i jednostek, konstatował wielokrotnie Norwid, ale wiele innych racji, których wspólnym mianownikiem był niedorozwój ludzkich sumień („Nie-prze-palony jeszcze glob, Sumieniem!”).

Już dwadzieścia lat wcześniej, w odpowiedzi na krytykę swych Listów o Emigracji, poeta pisał:

Nie wyobrażaj sobie, proszę, iż pieniędzy brak nędzy jest powodem: pieniędzy nie brak - życia brak.

${ }^{65}$ A. ChoJnAcki, ,, Socjalizm”, w: Cypriana Norwida ksztalt prawdy i miłości. Analizy i interpretacje, pod red. S. Makowskiego, Warszawa 1986, s. 75.

${ }^{66}$ Zob. J. ILuK, Kościót antyczny wobec pieniadza i kapitału. Od Nowego Testamentu do pism Ojców Kościoła, w: Pieniądz w literaturze i teatrze, s. 8-28 oraz J. Ossowski, Niebo dla bogaczy, w: Pieniadz w literaturze i teatrze, s. 29-39; Bogactwo, w: Stownik teologii biblijnej, pod red. X. Leon-Dufoura, przeł. K. Romaniuk, Poznań 1994, s. 86-89.

${ }^{67}$ Św. Klemens AleKsandryjsKi, Który człowiek bogaty może być zbawiony?, przeł. ks. J. Czuj, wstęp i oprac. ks. J. Naumowicz, Kraków 2012, s. 65. 
I zgody nie brak - życia brak! (Odpowiedź krytykom „Listów o emigracji”, PWsz VII, 35).

W latach 60. przekonywał Joannę Kuczyńską:

[...] Szlachetna Pani ma zupełną słuszność po szczególe co do wzajemnej pomocy społeczeństw i ludów. Ale... jednej rzeczy brak (wcale nie pieniędzy), brak jednej tylko rzeczy -ludzi! (List do J. Kuczyńskiej, PWsz IX, 300).

Obserwując niemrawość wszelkich poczynań socjalnych i dzieł miłosiernych, zauważał, że pieniądz najczęściej stawał się wymówką, a nie rzeczywistym powodem zaniechania działań. Prawdziwym motywem obojętności nie była wcale „niemożność pieniężna”, lecz chciwość i lenistwo serca. Widział to także podczas klęski głodu w Algierii:

[...] w tej chwili w Banku Francuskim leży

Miliard-pięć kroć milionów fr. w gotówce (!)

$[\ldots]$

Otóż z tym wszystkim, chociaż to bardzo jasne i matematycznie-pewne, jednak jest głód w Algierii, i nawet dlatego właśnie czasem bywa głód, że tyle pieniędzy leży (contradiction apparente) (List do J. Kuczyńskiej z 1868 roku, PWsz IX, 338).

Nie sposób zrozumieć ekonomiczną problematykę Vade-mecum bez lektury stanowiącego doń ważne preludium poematu Praca z roku 1864. Na przekór wszelkim „szkołom realnym”, to jest ówczesnym teoriom organicystycznym (głoszonym w kraju po katastrofie powstania styczniowego) i zwolennikom polityki realnej, rozmaitym koncepcjom etycznym (jak hedonizm, egoizm), a także ideom socjalistycznym, Norwid nie czynił tam pieniądza bezpośrednim celem ludzkiego wysiłku, a nawet obrażał iluzoryczność ekonomicznych i historiozoficznych teorii opartych wyłącznie na zysku. Punkt wyjścia każdego ludzkiego wysiłku stanowi w jego koncepcji duchowy ład, intelektualna rozwaga, uporządkowanie aksjologiczne. Punktem dojścia jest zmartwychwstanie. Jest to porządek chrześcijańskiej ekonomii zbawienia:

Głos brzmi w twej piersi: „Postradałem Eden!”

Głos brzmi nad tobą: „Pracuj z potem czoła.”

- Ekonomistów zbierz wszystkich i nagle

Spytaj ich, co jest pracy abecadłem?

[...]

Zacznij ... by w głowie nie było zawrotu,

$[\ldots]$ 
Wyrobić musi pierw umysłu stałość, Bez której nie ma siły - - nawet zysku!

Więc prac początek, prac pierwsza litera,

Nie to, co wasza dziś realna szkoła

Uczy - zarówno płytka, jak nieszczera.

„Pracować musisz zawsze z potem CZOŁA.”

- Spustoszonemu mów ty narodowi,

Niech się wzbogaci jak można najprędzej,

A mając posag resztę postanowi,

Do-rychtowawszy do onych pieniędzy:

Naucz, by jednym krokiem się przerzucał

Z historii-jatek krwawych do warsztatów,

Naucz, by się tak śmiał, jak zasmucał,

Wybawisz naród... lecz automatów! (...)

Nie! - pracą pierwszą jest: umysłu-stałość!

(PWsz I, 388).

Odejście od romantyzmu, idealistycznie pojmowanych wielkich obowiązków moralnych, na rzecz groszoróbstwa, wiedzie - w myśl poetyckiej rozprawy socjalnej Norwida - przede wszystkim do deformacji człowieczeństwa (duchowość zostaje zastąpiona przez automatyzm). Wnikliwa obserwacja współczesnych społeczeństw demokratycznych, „wolnych jak pieniądz”, „zbogaconych” i ,,ideałowi niepodległych w niczem”, nasunęła poecie wniosek (nie tezę!), iż samo ,posiadanie" nie chroni bynajmniej przed dziejową katastrofą. Może nawet stać się jej przyczyną. Przypomnijmy, że poemat Praca powstał w czasie, gdy w zbudowanych na etosie ekonomii i stanowiących symbol szybkiej drogi do finansowego sukcesu Stanach Zjednoczonych toczyła się krwawa wojna secesyjna (1861-65), stymulowana przez europejskich bankierów zainteresowanych zyskami z zaopatrywania obu stron konfliktu w broń oraz udzielaniem kredytów na naprawy zniszczeń z lichwiarskimi odsetkami. Autor bestselerowej Wojny o pieniądz - Song Hongbing przedstawiał te wydarzenia następująco:

[...] kalkulacje były proste: ogromne zniszczenia i wydatki wojenne będą wymagały olbrzymich nakładów finansowych, a to zmusi rządy do zaciągania wysokich kredytów, które będą najsmakowitszym i najbardziej obfitym daniem na bankierskim stole ${ }^{68}$.

W wojnie secesyjnej, w której do walki zmobilizowano około 3 milionów ludzi (10\% populacji kraju), śmierć poniosło blisko 650 tysięcy. W pył obrócono

${ }^{68}$ S. Hongbing, Europejscy bankierzy $i$ wojna secesyjna, w: tenże, Wojna o pieniądz. Prawdziwie źródła kryzysów finansowych, przeł. T. Sierakowski, t. 1, Wrocław 2010, s. 50. 
wówczas majątek wart około 5 miliardów dolarów. W ten sposób i ci „zbogaceni” (Amerykanie) szli na „pastwę” ,historii-orłowi”:

Jest tam i plemię, co inaczej żyło:

Porozkiełznanych spuścizną warsztatów,

Które się więcej niż kto zbogaciło (!),

Najrealniejszych pełne demokratów -

Ideałowi niepodległe w niczem -

Wolne jak pieniądz, co się toczy krągło;

I wiem, że smaga je tatarskim biczem,

Los ów, darzący pierwej ciszą ciągłą...

- wiem, że już milion blisko w pień wycięto

Tych zbogaconych i tych zapłaconych,

Doganiających się ofiarą świętą,

A kapitałów żądzą wyścignionych:

$\mathrm{Ci}$ - z Indian śmieją się...

(PWsz I, 389-390).

Życie Norwida przypadło na „bajeczne lata” Ameryki ${ }^{69}$, czasy kalifornijskiej „gorączki złota” (1848-1849), rozwoju żeglugi parowej i kolei, niebywałego bumu inwestycyjnego, rozkwitu banków i pojawienia się symbolu Ameryki: dolara (zaczęła wybijać go w srebrze w roku 1840 państwowa mennica USA). W latach 60. Ameryka wyszła już na czoło światowego wyścigu rozwojowego na świecie ${ }^{70}$. Poeta miał okazję dobrze poznać społeczeństwo „najrealniejszych demokratów” w latach 50. XIX wieku ${ }^{71}$. W jego Pracy odzywa się echo tych amerykańskich doświadczeń. Polemizując ze współczesnymi wojnie secesyjnej koncepcjami organicystycznymi w Polsce, Norwid wskazuje współczesnym, iż historia udowodniła właśnie (za oceanem), że posiadając wyłącznie bezideowe, „złoto”, nie zawsze można „resztę postanowić”, że owa „reszta” jest tak naprawdę fundamen-

${ }^{69}$ Zob. S. BratKowski, Nieco inna historia cywilizacji. Dzieje banków, bankierów i obrotu pieniężnego, wyd. II, Warszawa 2010, s. 329-336.

70 Zob. tamże, s. 369.

${ }^{71}$ Notabene w Ameryce znalazł się też związany z Norwidem (za sprawą pożyczonego paszportu, która otworzyła przed poetą berlińskie więzienie) Aleksander Jatowt (pseud. Jakub Gordon), uciekinier z carskiego zesłania. Kilkanaście lat później niż Dickens (ten ostatni odwiedził on Amerykę dwukrotnie: w latach 1842 i 1868),w zupełnie innym tonie niż poeta angielski, opisał on zachodnią cywilizację pieniądza: nieustanne zajęcie interesami i nakierowanie wyłącznie na „brzęczącą monetę”, zawiść i plotki, nowobogacką ,arystokrację wieprzową”, ale także otwartość, demokratyczne relacje społeczne, wolność oraz nieograniczone możliwości awansu i rozwoju. Zob. M. JaTOwT, Przechadzki po Ameryce, Berlin-Poznań 1866; tenże, ,, Wyttumaczę wam, skąd wzięła się Ameryka", Warszawa 1979. 
tem, bez którego buduje się przyszłość na piasku. Nawet na planie historii argument kapitałowy okazał się zupełnie nieprzekonywającą i niewystarczającą racją przetrwania.

Nietrudno zauważyć uderzającą zgodność wniosków Norwida zawartych w Pracy z konstatacjami Georga Simmela, autora Filozofii pieniądza (1900): cechą kultury pieniądza jest narastająca wolność w sensie negatywnym („od”) analogiczna do nieskrępowanej wolności pieniądza („Wolne jak pieniądz, co się toczy krągło”), ale i „monetarna” bezosobowość, nijakość, bez-idealizm ${ }^{72}$.

Kontynuację tej tematyki i zarazem wyraźną polemikę z poglądami współczesnych „reformatorów” oraz utopistów na temat tego, „co jest pracy abecadłem”, stanowi ogniwo Vade-mecum zatytułowane Prac-czoło:

Wyrobić musi pierw: umysłu-stałość,

Bez której nie ma sił, ciągu ni zysku.

Więc prac początek, pierwsza prac litera

Nie tam, gdzie wasza dziś realna-szkoła

Uczy - zarówno płytka, jak nieszczera:

Pracować musisz zawsze z potem-CZOŁA!

Reformatorów zbierz wszystkich i nagle

Spytaj ich: co jest pracy abecadłem?

Zacząć mam z czego? gdy na skały wpadłem

Lub wiatr ustąpił, zerwawszy pierw żagle -

Od czego zaczaćć czy - od dłoni-potu?

Lub ramion-potu?... gdy brak i narzędzi,

Gdy wkoło otchłań, a ty - na krawędzi:

Zacznij... by w głowie nie było zawrotu -

Więc głos ogromny znów jak pierwej woła:

„Musisz pracować z potem twego czoła!"

Spustoszałemu powiedz Narodowi:

Niech się zbogaci jak może najprędzéj,

A mając posag, resztę postanowi,

Do-rychtowawszy [do onych pieniędzy]

[Końca brak.]

(Prac-czoło, PWsz II, 91-92).

${ }^{72}$ Zob. G. Simmel, Filozofia pieniądza. 
W koncepcjach Norwida-myśliciela praca związana jest nie z kapitałem, ale z ,heroizmem” i „tworzeniem” (por. Bohater, PWsz II, 107), a w perspektywie teleologicznej - ze zbawieniem. Poeta przywraca jej sensy biblijne: ekspiacyjny i soteriologiczny, niemierzone doczesnym zyskiem, a nawet pozostające z nim w pewnej eschatologicznej kolizji.

Bohaterem innego liryku z cyklu Vade-mecum jest utożsamiony z pieniądzem „sukces”. Semantyka tego robiącego zawrotną karierę w XIX wieku słowa została przez poetę wyraźnie spolaryzowana ze znaczeniami, jakie niesie starożytne „zwycięstwo" (victoria). Utożsamienie tych pojęć uznał Norwid za jedną z największych omyłek współczesności:

S u k c e s bożkiem jest dziś - on czarnoksięstwo

Swe rozwinął, jak globu kartę;

Ustąpiło mu nawet i Z w y c i ę s t w o

Starożytne - wiecznie coś warte!

Aż spostrzeże ten tłum u swej mogiły,

Aż obłędna ta spostrzeże zgraja:

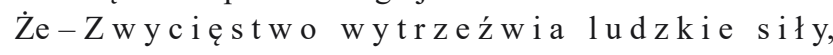

Gdy Sukces - i owszem - rozpaja!...

(Omyłka, PWsz, II, 122).

Szczególnie sugestywną wizję industrialnej cywilizacji zachodniej „w jej codziennych konkretach" ${ }^{\text {"3 }}$ przynosi liryk Stolica (PWsz II, 38-39). Zawarte w nim pełne dramatyzmu migawki z życia nowoczesnych metropolii przemysłowych, będących miejscem koegzystencji kapitalistów i proletariatu - obrazy wiernie przeniesione z ulic znanych poecie stolic: Londynu, Paryża czy Nowego Yorku przywodzą na myśl egzempla z pism socjalistów. W wierszu tym pojawiają się, niczym we współczesnej mu lub niewiele późniejszej nowelistyce i powieści pozytywistycznej, bohaterowie nowych, kapitalistycznych czasów oraz współczesne realia społeczne: fabrykanci i ,pokwitowani z prac" robotnicy; licha wypłata tych ostatnich starczająca ledwie na „kęs chleba”, spowijająca fabryczną rzeczywistość atmosfera nijakości, pośpiechu i niepokoju:

Ruchy dwa i gesty dwa tylko:

Fabrykantów, ścigających coś z rozpaczą,

73 S. SAwICKI, Religijność liryki Norwida, w: Polska liryka religijna, pod red. S. Sawickiego, P. Nowaczyńskiego, Lublin 1983, s. 244. 
I pokwitowanych z prac, przed chwilką, Co - tryumfem się raczą...

4

Konwulsje dwie, i dwa obrazy:

Zakupionego z góry nieba,

Lub - fabrycznej ekstazy

$\mathrm{O}$ - kęs chleba.

(PWsz II, 38-39)

Przed oczami czytelnika rozciąga się zatem widok na „wielkie miasto” „za bogactwy goniące” w kilka milionów „śmiertelnych”. To

Obraz dziewiętnastowiecznej stolicy - Paryża, - pisał Mieczysław Jastrun - widziany okiem nie tylko wielkiego artysty, ale i człowieka o głębokiej moralności, orientującego się, w jakiej godzinie dziejów przesuwa się ulicą „stolicy świata” ten tłum w czerni stoików, thum, który w przeciwieństwie do ich apathei, w ciągłym ruchu, w pościgu z pieniądzem znajduje cel życia ${ }^{74}$.

Pieniądz jest przedmiotem marzeń i rozpaczliwych wysiłków obu stron tego nieludzkiego wyścigu: zarówno fabrykantów, jak i uciskanych przez nich robotników. Posiadaczy i nędzarzy łączy wspólne wyobrażenie, że stanowi on przepustkę do raju. Różnica polega na stopniu, w jakim pragnienie posiadania ,nieba”, już tu i teraz, może zostać zaspokojone: kapitaliści są w stanie „niebo” dla siebie „,zakupić”, nędzarze przeżywają jedyną dostępną im formę „ekstazy”, żując kawałek chleba. To oczywiste, że Norwid dystansuje się do bogaczy, których nienasycona pożądliwość popycha ku coraz to nowym zdobyczom kosztem życia i godności innych, ale inaczej niż bezkrytycznie afirmujący proletariat socjaliści spogląda również z dystansem na dramatyczne zmagania wielkomiejskiej biedoty. Nie ulega fałszywemu miłosierdziu ani ułudzie socjalistycznych utopii, ma bowiem świadomość, że tak biedni, jak i bogaci mieszkańcy „stolicy” osiągnęli krańcowy etap merkantylizacji umysłów i materialistycznego zniewolenia, choć każda z tych grup na inny, dostępny jej sposób. Twierdzenie, iż ludzie ci ,ścigają coś” jednoznacznie sugeruje nieokreśloność i nijakość ich celu; pogoń za pieniądzem jest drogą w niewiadomym kierunku, perspektywą wyzutą z wartości, w gruncie rzeczy nihilistyczną (owo „coś” równie dobrze może okazać się ,;niczym”). Duchowa pustka nihilizmu skutkuje rozpaczą - jest nią podszyty nawet „triumf” kapitalistów. Konkluzja wiersza sprowadza się zatem do stwierdzenia, że materialistyczne bałwochwalstwo mamony kryje w sobie nihilizm i rozpacz.

${ }^{74}$ M. JASTRUn, ,, Stolica”, w: Cypriana Norwida ksztalt prawdy i mitości, s. 89. 
W Norwidowym opere magno „rozpacz i pieniądz” staną się kwintesencją całego zachodniego świata, chrześcijańskiego już tylko nominalnie. Ostatecznie pieniądz zajmie w nim miejsce odpowiadające jego randze w ówczesnym życiu społecznym i na planie historycznym:

Rozpacz i pieniądz - dwa słowa -

Łyskają bielmem jej źrenic.

Skąd idzie?... sobie to chowa.

Gdzie idzie?... zapewne, gdzie nic!

Takiej-to podobna jędzy

Ludzkość, co płacze dziś i drwi;

- Jak historia?... wie tylko: „krwi! ...”

Jak społeczność?... tylko: ,pieniędzy!...”

$$
\text { (Larwa, PWsz II, 30) }{ }^{75} \text {. }
$$

Godne podkreślenia jest owo historiozoficzne spostrzeżenie Norwida, że kult pieniądza (na płaszczyźnie społecznej) przekłada się w dziejach człowieka zawsze na „krew” z tego prostego powodu, że chciwość skutkuje polityką gwałtu. Prawdę tę wypowiedział Norwid jeszcze raz w swym przedśmiertnym resumé dziewiętnastowiecznej polityki i historii:

[...] kilkadziesiąt milionów trupa, łez i opchanych worków fałszywą monetą" (List do K. Górskiej, PWsz X, 155).

Notabene do podobnego wniosku dochodził u kresu swych ponad 800-stronicowych analiz ekonomicznych Marks:

Jeżeli pieniądz, wedle słów Augiera ${ }^{76}$, ,przychodzi na świat z krwawym piętnem na policzku”, kapitał rodzi się ociekając krwią i brudem wszystkimi porami, od stóp do głowy ${ }^{77}$.

Vade-mecum przynosi jeszcze jedno szokujące określenie zachodniej, kapitalistycznej rzeczywistości wieku XIX: „Syberia pracy i pieniędzy, gdzie wolnym grób" ${ }^{, 78}$ :

75 Zob. M. Żurowski, , Larwa” na tle porównawczym, „Przegląd Humanistyczny” VII: 1963, nr 6 (39), s. 15-34.

${ }^{76}$ Mowa o dziele Marie Augier, Du credit public, Paris 1842, s. 265.

77 K. Marks, Kapital, t. 1, s. 820.

${ }^{78}$ Podobne wstrząsające pejzaże moralne Europy Norwid kreślił już wcześniej, np. w lirykach Pieśn od ziemi naszej oraz Rzeczywistość i marzenia:

Od wschodu - mądrość-kłamstwa i ciemnota,

Karności harap lub samotrzask z złota, 
Wrócicież kiedy? - i którzy? i jacy? -

Z śmiertelnych prób,

W drugą Syberię: pieniędzy i pracy,

Gdzie wolnym - grób!

Lub pierw, czy? obie takowe Syberie,

Niewoli dwóch,

Odepchnie nogą, jak stare liberie,

Wielki-Pan... Duch!

(PWsz II, 58 ).

Wiesz Syberie jest wstrząsającym świadectwem narodzin nowych form ucisku, które wyłoniły się zza horyzontu nowoczesności. Wywołująca martyrologiczne skojarzenia metafora „Syberia pieniędzy” miała i ma dla Polaków wymowę tragiczną. Poszerzenie pola semantycznego tego geograficznego terminu nastąpiło w języku polskim już w pierwszej połowie XIX wieku, gdy zaczęto określać nim nie tylko ściśle przypisane doń tereny Azji Północnej, ale i wszystkie miejsca katorgi Polaków na Wschodzie (w tym Ural oraz Kaukaz). U Norwida proces pansematyzacji posunięty jest jeszcze dalej i ma charakter wręcz prowokacyjny ${ }^{79}$. Syberia to cały obszar zniewolenia duchowo-moralnego człowieka, także i ten wykreślony przez nowy despotyzm, już nie polityczny a ekonomiczny. Syberią bis jest zachodnie dominium pieniądza, którego tyrania równoważy carską politykę gwałtu i zbrodni. Jest to jedno z najcięższych oskarżeń, jakie kiedykolwiek posta-

Trąd, jad i brud.

Na zachód - kłamstwo-wiedzy i błyskotność, Formalizm prawdy - wnętrzna bez-istotność, A pycha pych!"

(Pieśń od ziemi naszej PWsz I, 123);

- Zresztą, kto ciało ma - ciałem, kto nerwy Nerwami, myśl kto ma, to myśli kwotą Musi opłacać czynsz lub kopać złoto...

-Bogdajby duszy w końcu nie żądano...

(Rzeczywistość i marzenia, PWsz I, 227).

79 O śmiałości tego Norwidowego posunięcia, polegającego na przedefiniowaniu sakralnego słowa-symbolu, oznaczającego „polską Golgotę”, pisał kiedyś Waldemar Smaszcz: „Używając tej nazwy w innym znaczeniu, poeta jakby zdesakralizował ją, niemalże profanował”. W. SMASzCz, „Syberie”, w: tenże, Trzy analizy, „Poezja” 1983, nr 4-5, s. 181. 
wiono zachodniemu, demokratycznemu światu, zawsze dumnie sytuującemu się w opozycji do azjatyckiego (w tym rosyjskiego) barbarzyństwa.

Vade-mecum odsłania nie tylko absurdy XIX-wiecznych utopii ekonomicznych, pokazuje też drugą stronę społecznego medalu: porażającą obojętność elit na nędzę rzesz:

2

Cywilizacji dwie widzę ustawnie:

Jedna, chce wszystko odkrywać na serio,

Druga, chce wszystko pokrywać zabawnie,

Świetną liberią!... [...]

4

Zakrywająca?... cieszy znów inaczéj -

Pokaż jej łez zdrój?... ona odpowiada:

„Nie trzeba zważać na to... co? to znaczy!...

Może - deszcz pada."

(Sieroctwo, PWsz II, 42-43).

Paradoksem czasów Proudhona i Marksa było to, że w sferach wyższych każdy odruch wrażliwości na nędzę był kwalifikowany jako osłuchana (i w związku z tym niebudząca rezonansu) propaganda socjalistyczna. Stawiający sobie za cel poruszenie sumień socjalizm zabijał się swą własną bronią:

Byłem wczora w miejscu, gdzie mrą z głodu -

Trumienne izb oglądałem wnętrze;

Noga powinęła mi się u schodu,

Na nieobrachowanym piętrze!

$[\ldots]$

Muszę dziś pójść do Pani Baronowej,

Która przyjmuje bardzo pięknie,

Siedząc na kanapce atłasowej --

Cóż? powiem jej...

... Zwierciadło pęknie,

Kandelabry się skrzywią na realizm,

I wymalowane papugi

Na plafonie - jak długi -

Z dzioba w dziób zawołają: „S ocjalizm!”

$($ Nerwy, PWsz II, 135)

${ }^{80}$ Gomulicki twierdził, iż wiersz ten jest poetycką transpozycją wizyty Norwida i Konstancji Górskiej („Baronowej”) u głodującej i żyjącej „,z dzieciątkiem swym w nieopłaconym i nieopalo- 
Jak pisał Bogdan Owczarek, kontrast przedstawionych w wierszu ,światów i środowisk społecznych jest zbyt wielki, aby możliwy był między nimi jakiś kontakt, słowa o nędzy i głodzie wypowiadane w salonie są w istocie nieme, pozostaną bowiem źle zrozumiane lub zakrzyczane" ${ }^{\circledR 1}$.

Vade-mecum mówi o pieniądzu, kapitale i pracy nie zawsze ze śmiertelną powagą; Norwidowi zdarza się też uderzyć w tony humorystyczne lub ironiczne, czego świetnym przykładem jest napisana jeszcze w 1865, a później włączona do cyklu humoreska Co stychać?. To kapitalna satyra na skrajny pragmatyzm, żartobliwie proponująca nadanie merkantylnych znaczeń nawet pospolitym gestom, jak kichnięcie czy poprawianie krawatu, by mogły one stać się szybką, niewerbalną informacją o stanie giełdy bądź cenach bawełny. Mimo pozorów tematycznej „lekkości” utwór ten skrywa przerażającą prawdę o karykaturalnym wynaturzeniu relacji międzyludzkich pod wpływem pieniądza:

- Wkrótce albowiem wszystko Ludzkość z-użyteczni,

Ludzie będą, dla wprawy w gimnastykę, grzeczni;

Jak kichnie kto?... będzie to hasłem dla sąsiada,

Że Bursa stoi słabo i że renta spada -

Jak poprawi krawatę, prosty z tego wniosek,

Że wiele jest o cenach bawełny pogłosek.

„Jak się masz?” - będzie stawką, a „bądź zdrów” - wykrętem,

Panny będą rachować Fijołki z procentem;

Arbuzy pójdą w górę; Kapusta czerwona

Zburczy Różę stolistną, że nie oceniona [...]

(Co stychać?, PWsz II, 93).

W ostatnim wersie zwraca uwagę kapitalna gra słów (w odniesieniu do róży): „nieoceniona” znaczyć może zarówno: drogocenna, nieoszacowana, unikalna, a więc piękna i wyjątkowa, jak i (tym razem po kupiecku): „niewyceniona”, niezmierzona ekonomicznie, nieopatrzona metką i ceną, a więc piękna „bezużytecznie”, niedająca się szybko spieniężyć.

Dokonany przegląd pozwala stwierdzić, że Vade-mecum jest tomem poezji bezprecedensowym (na tle wcześniejszej polskiej poezji romantycznej) oraz niesłychanie nowoczesnym nie tylko ze względu na nowatorstwo formy; jest nim

nym mieszkaniu" (DW XII, 137) wdowy - Jadwigi Glaubrecht. Wydarzenie to relacjonował poeta w liście do J. Kuczyńskiej (DW XII, 137-138), cytując w nim słowa, które wyrzekł do oburzonej niesprawiedliwością społeczną i obojętnością społeczeństwa Górskiej: „,czy to dla Pani jest nie znanym jej alfabetem, którego dopiero pierwsze głoski zaczynasz Pani widzieć?” (tamże).

${ }^{81}$ B. OwCZAReK, ,Nerwy”, w: Cypriana Norwida ksztalt prawdy i miłości, s. 113. 
także z powodu śmiałości, z jaką podejmuje w mowie wierszowanej współczesną, niewdzięczną i „suchą" tematykę ekonomiczną; z jaką wprowadza ,wulgarne" i „niepoetyczne” słowa zaczerpnięte z „, codziennej prozy życiowej” 82 , jak pieniądz, kapitał, bursa, fabrykant, cena, stawka, bank... Notabene równie odważnie szermował Norwid budzącym w salonach zgrozę słowem „kał”, które w nieodległej przyszłości miało zostać z pieniądzem ściśle powiązane (przez Freuda). Dziś nie odczuwamy już ekstrawagancji posunięcia Norwida, ale w XIX wieku była ona dla odbiorców uderzająca. Maciej Żurowski zauważał:

Tematyka wielkomiejska nie ma u nas bogatej tradycji poetyckiej i jeszcze na początku międzywojennego dwudziestolecia była czymś drażniąco nowym ${ }^{83}$.

W obrębie tego zagadnienia największy bodaj niesmak i szok estetyczny wywoływała tematyka ekonomiczna, którą dopiero pozytywizm uprawomocnił nieco swym programem społecznej naprawy (ale to w prozie, nie w poezji!).

Norwidowska diagnoza sytuacji społecznej (,Jak społeczność?... tylko: „pieniędzy!...”) zaskakująco zgadza się z konstatacjami największych, najbardziej wpływowych myślicieli stulecia (Proudhona, Owena, Cieszkowskiego, Marksa, Fouriera, Leroux etc.), awansującymi pieniądz na sam szczyt określających tamtą merkantylną epokę zagadnień. Norwid, nie bez udziału własnej, bolesnej autopsji, bezdyskusyjnie uznał doniosłość problematyki ekonomicznej w całokształcie życiowego i społecznego „Serio”. Stosował nawet podobne jak ówcześni ekonomiści i reformatorzy środki obrazowania i perswazji (piekielna metaforyka Dantejska, ironia). Jednak poeta ten nie zamierzał zostać praktycznym ekonomistą-demagogiem. Jak zauważył Juliusz W. Gomulicki, tematyka Vade-mecum koncentruje się raczej wokół zagadnień antropologicznych, jak: „niedojrzałość człowieka”, „tragizm trywialnej rzeczywistości”, „nędza doczesności”, „tragedia cierpień moralnych”, „złudzenia postępu” etc. ${ }^{84}$. Mieczysław Inglot rozwijał tę myśl następująco: „Vade-mecum było jednym wielkim krzykiem chrześcijańskiego cierpienia, tzn. cierpienia niepozbawionego nadziei" ${ }^{85}$.

${ }^{82}$ Tamże, s. 26.

${ }^{83}$ M. ŻuRowski, s. 15. Autor zwraca jednak uwagę na fakt, iż rzeczywistość wielkomiejska nie pociągała Norwida (jak pociągała np. Baudelaire’a), budziła jego odrazę, był on tylko jej ,patetycznym świadkiem". Tamże, s. 18.

${ }^{84}$ Zob. J. W. Gomulicki, Wstęp do: Vade-mecum, oprac. J. W. Gomulicki, Warszawa 1962, s. $22-23$.

${ }_{85}$ M. Inglot, Opus magnum Norwidowskiej liryki. Rzecz o „,Vade-mecum”, w: tenże, Wyobraźnia poetycka Norwida, Warszawa 1988, s. 82. 
Norwidowska poezja nigdy nie wikła się w poszukiwania szczegółowych rozwiązań prawno-ekonomicznych (choć i te również Norwida interesowały, o czym świadczą jego uwagi spisane na marginesie pracy Cieszkowskiego czy projekty powołania emigracyjnego banku); ich historyczne formy uważa poeta za doraźne, przemijające i ex definitione niedoskonałe, skazane też na ewoluowanie niemal ad inifinitum („Jesteśmy dopiero ludźmi XIX wieku!”). Problem pieniądza rozstrzyga się w Vade-mecum zupełnie inaczej niż w ateizujących manifestach socjalistycznych, czyniących punktem wyjścia swych postulatów mniej lub bardziej zaawansowany nihilizm:

Ekonomiści bowiem 19-o wieku zapomnieli prawie, iż kamieniem filozoficznym pieniędzy nie złoto jest, ale Dekalog, ale Mojżeszowe „nie kradnij, nie pożądaj...” - ale, jednym słowem, Ideał, w myśli Przedwiecznego zapisany i przed-położony człowieczeństwu przez kategorie z-Bożnych, historycznych ciał, ojczyzn [...] (List do F. Wężyka, DW XI, 158).

Koncepcja postępu ukierunkowanego jedynie na tezauryzację, a dopiero w drugiej kolejności na „dorychtowanie do onych pieniędzy” godności i miłosierdzia, nie jest wizją twórcy Vade-mecum. Bolączki materialne wieku wymagają zdaniem autora właśnie że wyjścia poza perspektywę merkantylną i powrotu do świata aksjologii. Istota problemu kryje się bowiem w ludzkim sercu, w karłowatości człowieczeństwa (,,jednej rzeczy brak (wcale nie pieniędzy), brak jednej tylko rzeczy -- ludzi!" List do J. Kuczyńskiej PWsz IX, 300) i w niedorozwoju ludzkiego sumienia ( „Nie-prze-palony jeszcze glob, Sumieniem!” Socjalizm PWsz II, 19). W tym Norwidowskim „manifeście nowoczesnej poezji intelektualnej”86 , będącym, jak pisał Gomulicki, ,summą wieloletnich doświadczeń filozoficznych artystycznych autora" ${ }^{" 87}$, poeta podejmuje więc - jako (post)romantyk i chrześcijanin - próbę przywrócenia ,pieniężnych” spraw materialnych do ich pierwotnego kontekstu: duchowego i idealnego.

\section{BIBLIOGRAFIA}

Bratkowski S., Nieco inna historia cywilizacji. Dzieje banków, bankierów i obrotu pieniężnego, wyd. II, Warszawa 2010.

Сıсноскі M., Wieczna gra możliwości - rzecz o politycznym romantyzmie niemieckim. „Nowa Res Publica", nr 7-8 (118-119), lipiec-sierpień 1998, s. 42-44.

Cypriana Norwida kształt prawdy i miłości. Analizy i interpretacje, red. S. Makowski, Warszawa 1986.

${ }^{86}$ J. W. Gomulicki, Wstęp do: Vade-mecum, s. 18.

87 Tamże, s. 17. 
Czeczot K., Pospiszyl M., Romantyczny antykapitalizm, Warszawa 2018.

Fereerira N., Crédit et monnaie sociale chez P. J. Proudhon (1809-1865). „Revue de philosophie économique" 2011, nr 1 (vol. 12), s. 91-116.

Filozofia i myśl społeczna w latach 1831-1864, wybrał, wstępem i przypisami opatrzył A. Walicki, Warszawa 1977.

Gadamska-Serafin R., ,Czasy skończone!”? Norwid a koncepcje końca historii, w: Norwid wobec historii, red. E. Chlebowska, Ł. Niewczas, Lublin 2014, s. 435-476.

Gadamska-Serafin R., Pieniadz - ,, deus ex machina” w dramatach Norwida, w: Norwidowski świat rzeczy, red. G. Halkiewicz-Sojak, P. Abriszewska, I. Dobrzeniecka, D. Wojtasińska, Torun 2018, s. 349-390.

GAŚCIEWICZ M., Piekielna przestrzeń miasta - liryka Cypriana Norwida w perspektywie badań nad nowoczesnościa. http://biesiada.polon.uw.edu.pl/Piekielna.pdf (dostęp: 15.04.2019).

Gomulicki J. W., Zabłąkany pielgrzym. Rzecz o Ludwiku Norwidzie, „Przegląd Współczesny” 1935, nr 163-164, s. 245-258 oraz s. 391-403.

GomUlicki J. W., Norwidowa podróż przez piekło (Ze studiów nad geneza kształtem ,, Vade-mecum”), „Miesięcznik Literacki” 1966, nr 2, s. 5-14.

Gomulicki J. W., Ludwik Norwid. W: Polski Stownik Biograficzny, t. XXIII, Wrocław-Warszawa-Kraków-Gdańsk 1978, s. 201-202.

Hongbing S., Wojna o pieniądz. Prawdziwie źródła kryzysów finansowych, przeł. T. Sierakowski, t. 1, Wrocław 2010.

HöRISch J., Orzeł czy reszka. Poezja pieniadza, przeł. J. Kita-Huber i S. Huber, Kraków 2010.

Inglot M., Opus magnum Norwidowskiej liryki. Rzecz o „Vade-mecum”, w: tenże, Wyobraźnia poetycka Norwida, Warszawa 1988, s. 53-83.

Klemens AleKsandryjski św., Który człowiek bogaty może być zbawiony? przeł. ks. J. Czuj, wstęp i oprac. ks. J. Naumowicz, Kraków 2012.

Konarski S., Rosen (Rozen) Mathias, w: Polski Stownik Biograficzny t. XXXII, Wrocław 1989-1991. https://www.ipsb.nina.gov.pl/a/biografia/mathias-rosen-rozen?print (dostęp: 15.08.2019).

Kumar K., Utopian Thought and Communal Practice: Robert Owen and the Owenite Communities, „Theory and Society” vol. 1, nr 1 (luty 1990), s. 1-35.

KuZIaK M., Norwid-Marks. Dwie nowoczesności, w: O Norwidzie komparatystycznie, red. M. Siwiec, Kraków 2019, s. 59-76.

Liebich A., Between Ideology and Utopia: The Politics and Philosophy of August Cieszkowski (Sovietica, vol. 39), Dordrecht 1979.

Morawski W., Kronika kryzysów gospodarczych, Warszawa 2003.

Nieukerken van A., Norwid i scjentyzm - konteksty komparatystyczne (Auguste Comte, Pierre-Joseph Proudhon), w: O Norwidzie komparatystycznie, red. M. Siwiec, Kraków 2019, s. 13-57.

Pieniadz $w$ literaturze $i$ teatrze. Materiały z sympozjum ,, Temat pieniadza $w$ literaturze $i$ teatrze”. Uniwersytet Gdański, Gdańsk 17-18 stycznia 2000, red. J. Bachórz, Sopot 2000.

Polska klasyczna myśl ekonomiczna na tle angielskiej i francuskiej, red. U. Zagóra-Jonszta, Katowice 2009.

Romantyzm i nowoczesność, red. M. Kuziak, Kraków 2009.

Simmel G., Filozofia pieniądza, przekł. A. Przyłębski, Warszawa 2012.

Smaszcz W., Trzy analizy (,,Noc”, „Legenda”, ,Syberie”), „Poezja” 1983, nr 4-5 s. 170-183. 
Stefanowska Z., Norwidowski romantyzm, w: taż, Strona romantyków. Studia o Norwidzie, Lublin 1993, s. 79-80.

Trojanowiczowa Z., Dambek Z., przy współudziale J. Czarnomorskiej, Kalendarz życia i twórczości Cypriana Norwida, t. 1: 1821-1860, Poznań 2007.

Wheen F., Marks. Kapitał. Biografia, przeł. P. Laskowski, Warszawa 2007.

Żor A., Kronenberg. Dzieje fortuny, Warszawa 2011.

ŻUrowski M., ,LLarwa” na tle porównawczym, ,Przegląd Humanistyczny” VII: 1963, nr 6 (39), s. 15-34.

\title{
SPOŁECZNOŚĆ I HISTORIA, CZYLI PIENIĄDZ I KREW. EKONOMIA W VADE-MECUM NORWIDA
}

\begin{abstract}
Streszczenie
Temat pieniądza zajmuje w Vade-mecum poczesne miejsce, proporcjonalnie do pozycji, jaka przypadła finansom i ekonomii w koncepcjach polityczno-społecznych oraz filozoficznych XIX stulecia. Tematyka „kapitałowa” pojawia się między innymi w takich ogniwach cyklu, jak Socjalizm, Larwa, Stolica, Prac-czoło, Syberie, [Co stychać?], Nerwy. Norwidowskie opus magnum kształtowało się w atmosferze wielkiego przesilenia gospodarki kapitalistycznej: kryzysu światowego po wojnie secesyjnej (1866), którego skutki pokazał w pierwszym tomie swego Kapitału (1867) Marks. Słynna publikacja niemieckiego ekonomisty stanowi ważny, choć w sensie ideowym - biegunowo odległy, kontekst Norwidowskiego cyklu. Ważną inspiracją były natomiast dla poety czytane w latach 40 . dzieła Proudhona i zapewne innych socjalistów utopijnych (może Owena), proponujące rezygnację z dotychczasowych form pieniądza jako antidotum na kryzysy ekonomiczne i nędzę mas. W liście Norwida z 15 lipca 1867 roku (PW, IX, 297) pojawia się ponadto ślad lektury rozprawy Augusta Cieszkowskiego pt. Du Crédit, et de la Circulation (Paris 1839) oraz dowód kontaktów autora Vade-mecum z ekonomistą Ludwikiem Wołowskim, współzałożycielem i dyrektorem paryskiego banku Crédit Foncier de France (zał. w r. 1852), którzy przenieśli do Francji Napoleona III genialne pomysły kredytowe księcia Druckiego-Lubeckiego. Norwid podejmuje w Vade-mecum polemikę zarówno z utopijnymi pomysłami socjalistycznej gospodarki bezpieniężnej, jak i z polskimi koncepcjami organicystycznymi, osadzonymi na ekonomii zysku i wizji sukcesu gospodarczego. Dostrzega ich oderwanie od Dekalogu, kategorii „sumienia” i chrześcijańskiej soteriologii. Vade-mecum staje się próbą (romantyczną i chrześcijańską) przywrócenia spraw pieniężnych do ich pierwotnego kontekstu: idealnego i duchowego.
\end{abstract}

Słowa kluczowe: pieniądz w literaturze XIX wieku; ekonomia; kapitalizm; Cyprian Norwid; Vade-mecum. 


\title{
SOCIETY AND HISTORY, OR MONEY AND BLOOD. ECONOMY IN NORWID'S VADE-MECUM
}

\begin{abstract}
The subject of money occupies a prominent place in Vade-mecum, reflecting the significance of finance and economy in socio-political and philosophical theories of the nineteenth century. The question of "capital" emerges in many poems from the cycle, e.g. in "Socjalizm" [Socialism], "Larwa" [The Larva], "Stolica" [Capital City], "Prac-czoło" [The-Forehead-ofLabor]"Syberie" [Syberias], "(Co słychać?)" [How are you?] and "Nerwy" [Nerves]. Norwid's opus magnumwas written in the period of intense changes in capitalist economy, notably in the wake of the global crisis following the American Civil War (1866), whose consequences are discussed by Marx in the first volume of Capital (1867). The famous publication by the German economist constitutes an important context for Norwid's cycle, although the two are worlds apart in ideological terms. The poet was nevertheless greatly inspired by Proudhon's works, which he read in the 1840s alongside other utopian socialists (possibly Owen), who would propose abandoning money in its traditional form as an antidote to economic crises and mass poverty. Additionally, Norwid's letter dated 15 July 1867 (PW IX, 297) contains a trace of the poet's reading of August Cieszkowski's treatise Du Crédit, et de la Circulation (Paris 1839) and proof of contacts with the economist Ludwik Wołowski, co-founder and director of the Parisian bank Crédit Foncier de France (established in 1852). The above two men introduced some of the brilliant credit ideas developed by Prince Drucki-Lubecki to the France of Napoleon III. In Vade-mecum Norwid polemicizes both with utopian concepts of a socialist, moneyless economy and with Polish organicist ideas basing on profit economy and visions of economic success. Norwid recognized their departure from the Decalogue, the category of "conscience," and Christian soteriology. In this sense, Vade-mecum becomes a Romantic and Christian attempt to return the question of money to its original context: that of ideals and spiritual life.
\end{abstract}

Translated by Grzegorz Czemiel

Key words: money in nineteenth-century literature; economy; capitalism; Cyprian Norwid; Vade-mecum.

RENATA GADAMSKa-SERAFIN - doktor nauk humanistycznych, literaturoznawca, wykładowca na Wydziale Polonistyki Uniwersytetu Jagiellońskiego (Katedra Historii Literatury Oświecenia i Romantyzmu). Autorka ponad 60 publikacji z zakresu literatury i kultury polskiego romantyzmu, m. in. Człowiek w myśli i twórczości C. K. Norwida; „,Promethidion” Norwida $i$ „List Ojca św. do artystów” w epoce upadku piękna; ,, Ten sam jest Bóg” Norwid - Abd el-Kader-Ibn 'Arabi; ,,Lud Koranu - Lud Ewangelii”. Norwid o historii relacji chrześcijańsko-muzułmańskich; ,,Obliczem catym w niebo wryty”. Niebo Norwida; , Kosmiczny patriotyzm-kapusty-kwaśnej” i ,jajecznica narodowa”, czyli kulinaria $w$ dyskursie Norwidowskim; „Pamięć serca”. „Król-Duch” i kwestia Armenii; Norwid-polski Hafiz?; Norwid i sybiracy; Norwidowskie ,etruski” literackie. Adres: ul. Gołębia 20, 30-007 Kraków; e-mail: renia5555@wp.pl. 